FEDERAL RESERVE BANK OF SAN FRANCISCO

WORKING PAPER SERIES

\title{
Beggar thy Neighbor? The In-State, Out-of-State, and Aggregate Effects of R\&D Tax Credits
}

\author{
Daniel J. Wilson \\ Federal Reserve Bank of San Francisco
}

August 2007

Working Paper 2005-08

http://www.frbsf.org/publications/economics/papers/2005/wp05-08k.pdf

The views in this paper are solely the responsibility of the authors and should not be interpreted as reflecting the views of the Federal Reserve Bank of San Francisco or the Board of Governors of the Federal Reserve System. This paper was produced under the auspices for the Center for the Study of Innovation and Productivity within the Economic Research Department of the Federal Reserve Bank of San Francisco. 


\title{
Beggar thy Neighbor? The In-State, Out-of-State, and Aggregate Effects of R\&D Tax Credits ${ }^{1}$
}

\author{
Daniel J. Wilson \\ (Federal Reserve Bank of San Francisco)
}

First Draft: April 2005

This Draft: August 2007

\footnotetext{
${ }^{1}$ I thank Geoff MacDonald, Jaclyn Hodges, and Ann Lucas for superb research assistance. The paper has benefitted from comments from Daron Acemoglu, Jim Besson, Nick Bloom, Robert Chirinko, Diego Comin, Bronwyn Hall, Andrew Haughwaut, John Van Reenen, Fiona Sigalla, John Williams, and two anonymous referees. The views expressed in the paper are solely those of the author and are not necessarily those of the Federal Reserve Bank of San Francisco nor the Federal Reserve System.
} 


\begin{abstract}
The proliferation of $R \& D$ tax incentives among U.S. states in recent decades raises two important questions: (1) Are these tax incentives effective in achieving their stated objective, to increase R\&D spending within the state? (2) To the extent the incentives do increase $R \& D$ within the state, how much of this increase is due to drawing $R \& D$ away from other states? In short, this paper answers (1) "yes" and (2) "nearly all," with the implication that the net national effect of R\&D tax incentives on R\&D spending is near zero. The paper addresses these questions by exploiting the crosssectional and time-series variation in R\&D tax credits, and in turn the user cost of R\&D, among U.S. states from 1981-2004 to estimate an augmented version of the standard R\&D factor demand model. I estimate an in-state user cost elasticity (UCE) around -2.5 (in the long-run), consistent with previous studies of the R\&D cost elasticity. However, the R\&D elasticity with respect to costs in neighboring states, which has not previously been investigated, is estimated to be around +2.7 , suggesting a zero-sum game among states and raising concerns about the efficiency of state R\&D credits from the standpoint of national social welfare.

[Keywords: R\&D Tax Credits, R\&D Price Elasticity; JEL Codes: H25, H23, O18, O38]
\end{abstract}




\section{Introduction}

Over the past two decades, R\&D tax credits offered by U.S. states have become widespread and increasingly generous. This phenomenon is illustrated in Figure 1, which plots from 1981 to 2006 both the number of states offering R\&D tax credits and the average effective credit rate among those states. ${ }^{1}$ Minnesota led the way, enacting an R\&D tax credit in 1982, one year after the introduction of the federal R\&D tax credit. As of 2006, 32 states provided a tax credit on general, company-funded R\&D, and the average effective credit rate has grown approximately four-fold over this period to equal roughly half the value of the federal effective credit rate. ${ }^{2}$ In fact, in a number of states, the state tax credit is considerably more generous than the federal credit.

The proliferation of state R\&D tax credits raises two important questions. First, are these tax incentives effective in achieving their stated objective, to increase private R\&D spending within the state? Second, to the extent the incentives do increase R\&D within the state, how much of this increase is due to drawing R\&D away from other states?

There has been surprisingly little empirical research on either of these questions. Most previous work on R\&D tax incentives has investigated the effectiveness of the federal R\&D tax credit. Studies in this area generally follow the approach of estimating the elasticity of $R \& D$ with respect to its price (user cost), exploiting panel data variation across firms ${ }^{3}$, industries ${ }^{4}$, or countries ${ }^{5}$. These studies, and their general finding of a statistically significant $R \& D$ cost elasticity at or above unity, are frequently cited in debates over the efficacy of state R\&D tax credits.

It is not at all clear, however, that inferences based on existing firm-, industry-, or country-level data, which report only nationwide $R \& D$ expenditures for the unit of observation, can be extended to the state level. R\&D may be mobile across states so that the cost of R\&D in other states can affect how much R\&D is performed in any one state. Thus, the true aggregate $R \& D$ elasticity with respect to the cost of $R \& D$ (and R\&D tax credits), for a given state, is actually the difference between (the absolute

\footnotetext{
${ }^{1}$ The effect credit rate corresponds to the $k_{i t}^{e}$ term defined in Section 2.

${ }^{2}$ The statutory rate for the U.S. federal R\&D tax credit is $20 \%$. However, the credit itself is considered taxable income, and therefore the effective credit rate is $20 \%(1-0.35)=13 \%$, using 0.35 as the corporate income tax rate.

${ }^{3}$ See Hall [1993a]; Swenson [1992]; Berger [1993]; and McCutchen [1993].

${ }^{4}$ See Baily and Lawrence [1995] and Mamuneas and Nadiri [1996].

${ }^{5}$ See Bloom, Griffith, and Van Reenen [2002].
} 
value of) the elasticity with respect to the cost of doing $R \& D$ within the state and the elasticity with respect to the cost of doing $R \& D$ outside of the state. As I argue in more detail later in the paper, inferences based on the estimates from previous studies regarding the $R \& D$ cost elasticity that is relevant for analyzing state $R \& D$ tax credits are likely to be incorrect. The estimated elasticities from previous studies, which do not address R\&D mobility and external user costs, will at best provide only the internal (in-state) cost elasticity and at worse provide biased (away from zero) estimates of that elasticity.

This paper addresses the two questions posed above by estimating an augmented version of the standard R\&D factor demand model using the within/difference-indifference (DID) estimator with state-level panel data from 1981-2004. This estimator allows for state and year fixed effects. The elasticities of private R\&D with respect to its user costs (both in-state and out-of-state) are identified off of the variation in the user cost of R\&D across states and across time. An appealing aspect of using state-level information for this identification is that state-level variation in the user cost of $R \& D$ is driven entirely by variation in $\mathrm{R} \& \mathrm{D}$ tax credits and corporate income tax rates, both of which are arguably exogenous to firms' contemporaneous R\&D decisions. ${ }^{6}$ This approach of using tax code changes as natural experiments has been fruitly employed in the investment literature (see, e.g., Cummins, Hassett, and Hubbard 1994).

To facilitate comparisons to previous studies of the R\&D cost elasticity, I first estimate an R\&D cost elasticity omitting out-of-state R\&D costs (though these costs may be picked up, to some extent, in the year effects). The estimated elasticity is negative, above unity in absolute value, and statistically significant - a finding similar to those found in previous studies based on firm, industry, or country data. Adding the external R\&D cost - measured as a weighted average of R\&D user costs in neighboring states (weighting by spatial proximity) - to the regressions, I find the external-cost elasticity is positive and statistically significant, raising concerns about whether having state R\&D tax credits on top of federal credits is socially desirable (irrespective of the issue of the socially optimal federal credit rate). Moreover, the aggregate $R \& D$ cost

\footnotetext{
${ }^{6}$ The statement that cross-state variation is driven entirely by variation in $\mathrm{R} \& \mathrm{D}$ tax credits and corporate income taxes assumes that the opportunity cost of funds (the pre-tax expected rate of return) and the depreciation rate of $\mathrm{R} \& \mathrm{D}$ capital do not vary across states. The former should be true since capital markets are national (if not international). The latter should be true as long as the technological nature of the R\&D capital (and hence the rate at which it obsolesces) does not differ systematically across states.
} 
elasticity, which is the difference between the internal-cost elasticity (in absolute value) and the external-cost elasticity, is far smaller than previously thought. In fact, the point estimate I obtain for the aggregate elasticity is near zero in most specifications and is statistically insignificant in all specifications. Thus, returning to the two questions posed at the beginning of the paper, I find that state R\&D tax credits are indeed effective at increasing R\&D within the state. However, nearly all of the resulting increases appear to come at the expense of reduced R\&D spending in other states.

This last result contrasts sharply with previous studies which suggest that the aggregate $R \& D$ cost elasticity is at or above unity. The results in this paper suggest that previous results should be interpreted with caution. Because the external R\&D cost previously has been omitted from these types of regressions, the estimated coefficient on the own R\&D cost should be interpreted as an estimate of the internal-cost elasticity, not the aggregate-cost elasticity. Moreover, this internal-cost elasticity estimate may be biased due to the omitted variable, though my results suggest this bias is small. By explicitly measuring the external user cost and including it in the R\&D factor demand regression, I am able to estimate both the internal- and external-cost elasticities, and therefore obtain the aggregate-cost elasticity.

The contributions of this paper relative to the existing literature are fivefold. The first contribution is to provide identification of the in-state R\&D cost elasticity, which has not previously been estimated. Previous research generally has focused on federal R\&D tax incentives and their impact at the firm or country level, the results of which are not necessarily generalizable to the state level. What research has been done at the state level has typically focused on just one or two states (e.g., Hall and Wosinka [1999a], which focused on California, and Paff [2004] which focused on California and Massachusetts). ${ }^{7}$ The reason state level data on the user cost of R\&D has not previously been utilized appears to be due to the fact that the necessary data ingredients are not collected in a single source but rather must be obtained on a state-by-state and year-by-year basis - a very time-consuming process. ${ }^{8}$ This paper is the first to

\footnotetext{
${ }^{7}$ Somewhat of an exception is $\mathrm{Wu}(2003)$, who analyzes the effect of state R\&D tax credits and other fiscal policies on (in-state) R\&D spending for a set of 13 states from 1979 to 1995 . Including a dummy variable indicating whether or not a state has an $R \& D$ tax credit, Wu finds that the presence of a credit is positively associated with state $\mathrm{R} \& \mathrm{D}$ spending. This dummy variable approach, however, unlike the approach undertaken in this paper based on an $R \& D$ factor demand equation and measurement of R\&D user costs, can assess only qualitatively the impact of R\&D tax credits.

${ }^{8}$ This point was made in Hall and Wosinka (1999b): "Given the variability of incentives across
} 
construct a comprehensive state-level panel data set on after-tax $R \& D$ prices and the ingredients therein.

Second, this paper additionally considers the impact of out-of-state, or "external," R\&D costs on the level of in-state R\&D spending, an issue with important implications for optimal public policy and, indeed, one that is central to the current legal debate about the constitutionality of state business tax incentives. ${ }^{9}$ If reductions in the cost of doing R\&D out-of-state have a negative effect on a state's R\&D, then it raises the question of whether state $\mathrm{R} \& \mathrm{D}$ tax credits result in wasteful tax competition among states, competition that could be avoided if tax credits were offered only at the federal level. ${ }^{10}$ In fact, recent federal court decisions in the U.S. have declared that a state or local tax instrument may be unconstitutional if it treats in-state and out-of-state economic activity differently and if it can be shown empirically that the instrument adversely affects economic activity in other states (see Cuno v. DaimlerChrysler [2004] and the Supreme Court decisions cited therein). At the time of this writing, the U.S. Supreme Court is deliberating on Cuno v. DaimlerChrysler, which relates to an Ohio investment tax credit which was struck down by a lower court on grounds that it may have a negative effect on economic activity in other states, thereby violating the Commerce Clause of the U.S. Constitution. Analyses such as that done here could therefore be critical to informing this debate. ${ }^{11}$

states both in magnitude and design, one possible mode of analysis would be a comparative study that examined R\&D spending at the individual state level as a function of changes in the relevant tax legislation. Such a study could be of considerable interest (and would be similar in spirit to studies of the effects of infrastructure generally on economic growth), but would be time-consuming due to the necessity of collecting the relevant data, which does not come conveniently in one dataset. In particular, collecting the individual tax legislation histories for 50 (or even 35) states is a daunting task. Policy-makers may wish to consider such a project."

${ }^{9}$ Bloom and Griffith (2001) also look at the effects of external user costs (measured there as the R\&D user cost of the external country in which the own country does the most foreign direct investment), but they are unable to estimate these effects with any reasonable degree of precision.

${ }^{10}$ There is a rich literature on the theory side on the issue of tax competition over mobile capital, dating back to Tiebout's (1956) model of efficient tax competition. Many subsequent models, beginning with Oates (1972), yield wasteful tax competition (e.g., Wilson $(1986,1991)$ and Zodrow and Mieskowski (1986)). Yet other models, particularly so-called "Leviathan" models, have the implication that interjurisdictional tax competition can be welfare-enhancing by reducing government excess.

${ }^{11}$ See Stark and Wilson (2006) for a discussion of the importance of economic analyses to the jurisprudence of Cuno and related cases. 
Third, by simultaneously estimating the in-state and out-of-state R\&D cost elasticity, this paper is able to provide estimates of the net, or "aggregate," cost elasticity, which is relevant for the evaluation of national R\&D policy. The result obtained in this paper of a near-zero aggregate response of $R \& D$ to state tax credits (due to the offsetting effects of in-state and out-of-state credits) suggests that aggregate (national) social welfare could be increased by shifting R\&D subsidization entirely away from the states and toward the federal government.

A fourth contribution is the empirical integration of both federal and state R\&D tax credits. Despite the fact that state-level R\&D tax credits have come to account for a substantial share of the total fiscal subsidization of R\&D in the U.S., with over half of all states having credits and many states having effective credit rates that are similar to or greater than those offered by the federal government, state tax credits generally have been ignored in the firm- and country-level studies to date. As shown in Section 3 below, state and federal credit rates, along with state and federal corporate tax rates, interact (in rather complicated ways) to determine the true user cost of R\&D faced by a representative firm conducting $R \& D$ within a given state.

Lastly, the paper provides estimates of the effect of federal funding of industrial R\&D on private funding of industrial R\&D. Whether public R\&D complements or substitutes for private $R \& D$ is an important unresolved issue in the literature on R\&D policy (see David, Hall, and Toole 2000 for a review of the conflicting econometric evidence on this issue). With the exception of Mamuneas and Nadiri [1996], most previous studies of the R\&D cost elasticity have not controlled for this potentially complementary or substitutable input into firms' production functions. Like Mamuneas and Nadiri, I find that federal funding does in fact have a significant effect on private funding, with federal funding crowding out private funding.

Given that the results in this paper imply that the location of R\&D activity is at least partly dependent on the relative levels of R\&D subsidization among states, the paper is closely related to previous research investigating the effect of taxes on business decisions regarding location of physical investment and/or employment. These studies focus typically either within a country ${ }^{12}$ or across countries ${ }^{13}$ (see Buss [2001] for a survey of this literature). In general, these papers have found that the overall level of

\footnotetext{
${ }^{12}$ See, e.g., Carlton (1983); Papke (1987, 1991); Plesko and Tannenwald (2001); and Beaulieu, McKenzie, and Wen (2004).

${ }^{13}$ See, e.g., Wheeler and Mody (1992), Devereau and Griffith (1998), and Grubert and Mutti (2000).
} 
corporate taxes in a jurisdiction has a significant effect on either the level of investment or the number of business establishments in that location. ${ }^{14}$ Unfortunately, while these studies provide evidence on the effect of a tax change on the levels of economic activity in the changing jurisdiction, they do not provide guidance on how much of the effect is due to increased activity from existing in-state firms and residents versus activity that has relocated from other jurisdictions in response to the tax change.

The paper is organized as follows. In Section 2, I briefly describe the measurement of the user cost of R\&D at the state-level (this measurement is described in full detail in Appendix A) and I illustrate the tremendous variation in this user cost across states and across time. I also discuss the other data used in the analysis. In Section 3, I discuss the empirical model that I estimate and the econometric issues that arise. The results, including various robustness checks, are presented in Section 4. Section 5 concludes with a discussion of the policy implications of these results.

\section{R\&D User Costs Across States and Time}

\subsection{How R\&D tax credits work}

\subsubsection{Federal Tax Credit}

The U.S. Economic Recovery Tax Act of 1981 introduced an R\&D tax credit equal to $25 \%$ of qualified research and development expenses over a base level, defined by a firm's current sales multiplied by its average R\&D-sales ratio over the previous three years. ${ }^{15}$ The U.S. Internal Revenue Code (IRC) defines qualified research and development as the salaries and wages, intermediate/materials expenses, and rental costs of certain property and equipment ${ }^{16}$ incurred in performing research "undertaken to discover

\footnotetext{
${ }^{14}$ An exception is Plesko and Tannenwald (2001) who find state and local taxes have a negligible effect on business location decisions.

${ }^{15}$ In addition, the allowable credit was capped at twice the base. In the data construction of the R\&D user cost for a representative firm (described below), I assume this cap is non-binding. This assumption appears reasonable given that of the Compustat sample of firms analyzed in Hall (1993a), generally less than 10\% reached this cap in any given year (between 1981 and 1991).

${ }^{16}$ The definition of qualified R\&D expenses in the current (as of 2005) Internal Revenue code, section 41, is:

"(i) any wages paid or incurred to an employee for qualified services performed by such employee, (ii) any amount paid or incurred for supplies used in the conduct of qualified research, and (iii) under regulations prescribed by the Secretary [of Treasury], any amount paid or incurred to another person
} 
information" that is "technological in nature" for a new or improved business purpose. ${ }^{17}$ The IRC definition of qualified R\&D differ only slightly from the definition of $R \& D$ from the NSF. The NSF additionally includes depreciation and amortization charges on R\&D property and equipment. Accounting depreciation and amortization charges are a negligible share of total R\&D expenses. ${ }^{18}$

\subsubsection{State Tax Credits}

Companies pay corporate income taxes to states based on an apportionment of their total federal taxable income. ${ }^{19}$ The apportionment formulas differ to some extent across states. Some states use a formula based on a equally weighted average of property, payroll, and sales; some states double-weight sales in this average; and some states use a single-factor (sales) formula. In some states, companies may take a credit against their state taxable income equal to a percentage of their qualified R\&D expenditures over some base amount. In 2004, 31 states provided some form of tax credit on company-funded R\&D. ${ }^{20}$ The value of the credit varies from state to state depending on the credit rate, how the base amount is defined, and whether the credit itself may be "recaptured" (in the sense that it is considered taxable income). States generally use the federal definition of qualified research and development in their tax codes. As such, state R\&D tax credits generally are not targeted at particular technologies or

for the right to use computers in the conduct of qualified research."

Prior to 2002, Clause (iii) referred not to "computers" but rather "personal property."

${ }^{17}$ The qualification that the research be "technological" in nature was actually not in the 1981 tax code. It was added with the the Tax Reform Act of 1986 in an attempt to mitigate potential abuse of the tax credit (a problem often referred to as "relabeling").

${ }^{18}$ In its report, Research and Development in Industry: 2001 (NSF [2005]), the NSF reports that R\&D property and equipment depreciation costs account for $3.6 \%$ of total industrial R\&D.

${ }^{19}$ There are five states (Nevada, South Dakota, Texas, Washington, and Wyoming) that have no corporate income tax, though Texas does have a "Franchise" tax, which is quite similar to an income tax. (A franchise tax is a tax on either apportioned federal taxable income plus compensation for officers and directors or tangible assets.) Naturally, the four states with neither an income tax nor a franchise tax have no R\&D tax credit. Texas, though, enacted in 2001 a R\&D tax credit against franchise taxes.

${ }^{20} \mathrm{~A}$ handful of other states (e.g., Arkansas and Colorado) offer narrowly-targetted tax credits for spending in narrow types of R\&D (e.g., approved university research projects) or narrow geographic zones. These states often refer to these credits as "R\&D tax credits." However, in this paper, we use this term to mean credits for general company-funded industrial R\&D. 
industries. $^{21}$

In addition to (or instead of) R\&D tax credits, a small number of states (seven as of 1996 - see SSTI [1997]) offer exemptions on sales and use taxes for R\&D spending on plant and equipment. However, given that expenditures on buildings and machinery are excluded from both the NSF and IRS definitions of R\&D, these exemptions do not affect the user cost of NSF/IRS R\&D.

\subsection{Measurement of the R\&D User Cost}

Like most economic studies concerning $R \& D$, this paper treats $R \& D$ as an input into a firm's production function. The actual input is the services of R\&D capital (knowledge) formed by past and present R\&D expenditures net of depreciation (obsolescence). The price for this factor is the implicit rental rate, or user cost, after taxes. The Neoclassical formula for the after-tax user cost of capital, derived in the seminal work of Hall and Jorgenson [1967], can be adapted easily to apply to R\&D capital services. The user cost formula takes into account the real opportunity cost of funds, the economic depreciation rate, the income tax rate, the present discounted value (PDV) of tax depreciation allowances, and the effective tax credit rate. $^{22}$

Extending the standard Hall-Jorgenson formula to incorporate both state and federal tax considerations yields the following formula for the user cost of R\&D capital (per dollar of investment):

$$
\rho_{i t}=\frac{1-s\left(k_{i t}^{e}+k_{f t}^{e}\right)-z_{t}\left(\tau_{i t}^{e}+\tau_{f t}^{e}\right)}{1-\left(\tau_{i t}^{e}+\tau_{f t}^{e}\right)}\left[r_{t}+\delta\right],
$$

where $t$ indexes time. ${ }^{23}$ The subscript $i$ indicates a state-level variable while the

\footnotetext{
${ }^{21}$ An exception is Oregon, whose R\&D tax credit (of $5 \%$ over a 3-year moving average of previous $\mathrm{R} \& \mathrm{D})$ is available only for R\&D in the fields of "advanced computing, advanced materials, biotechnology, electronic device technology, environmental technology, or straw utilization." Of course, these fields collectively comprise a very large share of R\&D. Hence, in constructing Oregon's R\&D price, I assume the R\&D performed by the representative Oregon company is in one or more of these fields.

${ }^{22}$ With regards to R\&D done by U.S. multinational corporations, there is an additional tax consideration that I will not attempt to incorporate in the R\&D user cost formula due to its complexity. As Hines (1993) discussed in great detail, U.S. multinationals may receive tax benefits from performing $\mathrm{R} \& \mathrm{D}$ directed at foreign sales to the extent that they have unused foreign tax credits. The omission of this potential benefit of R\&D in the user cost data that I construct should not cause any bias in my empirical results since access to this benefit does not vary systematically across states.

${ }^{23}$ Bloom, et al. (2002) similarly adapt the standard user cost of capital formula for measuring an
} 
subscript $f$ is used for federal-level variables. $\quad r_{t}$ is the real interest rate and $\delta$ is the economic depreciation rate of the $\mathrm{R} \& \mathrm{D}$ capital. $\tau_{i t}^{e}$ and $\tau_{f t}^{e}$ denote the effective corporate income tax rates, while $k_{i t}^{e}$ and $k_{f t}^{e}$ denote the effective $\mathrm{R} \& \mathrm{D}$ tax credit rates. $z_{t}$ denotes the present discounted value (PDV) of tax depreciation allowances. $s$ is the share of R\&D expenditures that qualifies for special tax treatment (i.e., what the tax code calls "qualified" R\&D). How each of these tax variables are measured and the sources of the underlying data are discussed briefly here, and in greater detail in Appendix A.

In the United States, the effective federal and state corporate tax rates generally are lower than the statutory tax rates $\left(\tau_{i t}\right.$ and $\left.\tau_{f t}\right)$ because the taxes a firm pays to states are deductible from its federal tax liability, and often vice-versa. This makes $\tau_{f t}^{e}$ a function of $\tau_{i t}^{e}: \tau_{f t}^{e}=\tau_{f t}\left(1-\tau_{i t}^{e}\right)$; and $\tau_{i t}^{e}$ a function of $\tau_{f t}^{e}: \tau_{i t}^{e}=\tau_{i t}\left(1-\lambda \tau_{f t}^{e}\right)$, where $\lambda$ is the fraction of federal taxes that are deductible from state taxable income. The two equations can be solved in terms of the published statutory tax rates: $\tau_{f t}^{e}=$ $\frac{\tau_{f t}\left(1-\tau_{i t}\right)}{1-\lambda \tau_{f t} \tau_{i t}}$, and $\tau_{i t}^{e}=\tau_{i t}\left[\frac{1-\lambda \tau_{f t}}{1-\lambda \tau_{f t} \tau_{i t}}\right]$.

The present value of depreciation allowances, $z_{t}$, captures the tax benefit from firms being allowed to immediately expense qualified R\&D expenditures, which has been true in the U.S. since 1954. The immediate expensing implies $z_{t}=1$ for all $t$ in our sample.

The effective rate of an $R \& D$ tax credit depends on whether the credit applies to all qualified R\&D expenditures or only those expenditures above a designated base level, and, if the latter, how the base is defined. If the R\&D tax credit is nonincremental, i.e., it applies to all qualified R\&D (as in New York, West Virginia, and Hawaii), then the effective credit rate is simply the statutory credit rate: $k_{i t}^{e}=k_{i t}$. In the federal tax code and most states' tax codes, the R\&D tax credit applies only to incremental R\&D above some base level. In some cases, the base is the product of sales and the R\&D-to-sales ratio averaged over some fixed past time period. In other cases, the base is the product of current sales and a moving average of the R\&D-to-sales ratio over some number of recent years. As has been pointed out in numerous discussions of $\mathrm{R} \& \mathrm{D}$ tax credits, this moving-average formula drastically reduces the value of the credit, as current R\&D spending serves to lower, one-for-one, the amount of R\&D that qualifies for the credit in future years. For this reason, the federal government and

R\&D user cost. They construct R\&D user costs for nine OECD countries, including the U.S. (though their U.S. R\&D user cost does not take account of state-level R\&D tax credits). 
states generally have moved away from the moving-average formula in favor of a fixedperiod (which, since 1991, has been 1984-88 in federal tax code and in most state tax codes).

The effective credit rate also may be reduced by recapturing provisions. Some states in some years recapture - i.e., tax - part or all of the tax credit. The federal R\&D tax credit was not recaptured from 1981 to 1988; in 1989, 50\% of the credit was recaptured; since 1989, 100\% of the credit has been recaptured. Recapture provisions reduce a state's effective credit rate by $\omega_{i t} \tau_{i t}^{e} k_{i t}^{e}$ (and the federal effective rate by $\left.\omega_{f t} \tau_{i t}^{e} k_{i t}^{e}\right)$, where $\omega_{i t}$ is the share subject to recapture.

As described in detail in Appendix A, the specific details (credit rates, base definitions, and recapture provisions) of the R\&D tax credits for the 50 states plus the District of Columbia over the period 1981-2004 were compiled from a variety of sources. SSTI (1997) and Sigalla and Viard (1999) provided a useful starting point with their summaries of the $R \& D$ tax credits available at particular points in time. The principal sources of data, however, were state corporate tax forms obtained online. As for state corporate tax rates, rates were collected primarily from four sources: State Tax Handbook (various years), The Book of the States (various years), Significant Features of Fiscal Federalism (various years), and actual state tax forms.

Table 1 provides summary information regarding R\&D user costs for the 32 states with R\&D tax credits in place in 2006. For each of these states, the table shows the year in which the state first introduced an R\&D tax credit, the state's statutory credit rate (for the highest tier of $R \& D$ spending if the state has a multi-tiered credit), its top marginal corporate income tax rate, the type of base used in calculating the credit, the state's effective credit rate, and its marginal effective tax rate (METR) on R\&D capital. The METR is the percentage difference between the after-tax cost of $\mathrm{R} \& \mathrm{D}(\rho)$ and the pre-tax cost of $\mathrm{R} \& \mathrm{D}(r+\delta)$. This concept sometimes is referred to as the "tax wedge." A negative METR indicates that the state and federal governments, collectively, are subsidizing R\&D spending - i.e., it is cheaper in that state to invest in $R \& D$ than to invest in alternative tax-free assets with the same expected financial return.

As is clear from the table, the variation in METR's and user costs among states is driven primarily by variation in the effective credit rate. The amount of variation in the user cost has risen steadily over the past two decades, since Minnesota became the first state to enact a R\&D tax credit in 1982, as more and more states enacted 
these credits (and chose widely varying effective credit rates). This rise can be seen also in Figure 2, which shows the coefficient of variation in the R\&D user cost between 1981 and 2004. ${ }^{24}$ The large degree of cross-state variation towards the latter half of the sample is what allows one to identify the in-state and out-of-state effects of R\&D tax incentives.

In Appendix B, I provide time series plots for each state of the R\&D user cost (using top-tier credit rates), both in absolute terms and as a ratio to the average user cost over all states. The R\&D user cost in about half of the states follows a common pattern, dictated by changes in federal R\&D tax incentives. In general, these states made little or no changes to their corporate tax rate and never enacted an R\&D tax credit. The other roughly half of states, however, have deviated substantially from the federal pattern in terms of their $\mathrm{R} \& \mathrm{D}$ user cost.

\section{$2.3 \quad$ R\&D Data}

State data on industrial (company-performed) R\&D expenditures by source of funding (company, federal, and other) from 1981-2004 are available from the National Science Foundation (NSF) (Industrial Research and Development, various issues). These data are biannual (odd years) from 1981-1996 and annual from 1997-2004. Due to disclosure limitations, R\&D spending for small states is often missing. The severity of this problem varies from year to year as the sample size of the underlying survey varies, but generally declines over time. Data is available for nearly all states by the end of the sample. ${ }^{25}$

\footnotetext{
${ }^{24}$ The drop in 1995 is due in part to the temporary lapse in that year of the federal R\&D tax credit, which substantially raised the R\&D user cost in all states. The federal credit was reinstated for 1996 . The 1995 drop was also partly due to New Hampshire's permanent elimination of its R\&D tax credit in that year.

${ }^{25}$ In order to be sure that the data underreporting is not systematically related to any of the analysis variables, I have estimated results (1) based on a balanced panel of 11 large states from 1987-2004, and (2) using a Heckman two-step estimator to allow for potential data-reporting/selection bias. The results from each of these estimations were quite similar to those reported below.
} 


\section{Empirical Model}

\subsection{Static Model}

In order to analyze the determination of private (i.e., company-funded) R\&D conducted within a state, and therefore the impact of $\mathrm{R} \& \mathrm{D}$ tax credits, I begin by modeling the demand for R\&D capital by a representative firm in the economy.

Consider first the case where the firm's output in state $i$ in year $t$ is produced via a production function with a constant elasticity of substitution $(\gamma)$ between R\&D services $\left(R_{i t}\right)$ and other inputs. The first-order conditions for profit-maximization yield a standard factor demand equation relating $\mathrm{R} \& \mathrm{D}$ services $\left(R_{i t}\right)$ to its ex-ante user cost $\left(\rho_{i t}\right)$ and output $\left(Y_{i t}\right): \quad R_{i t}=\zeta Y_{i t} \rho_{i t}^{-\gamma}$, where $\zeta$ is the CES distribution parameter. Notice the elasticity of substitution, $\gamma$, is also the elasticity of R\&D with respect to its user cost (in absolute value). This factor demand equation (in its log-linear form) forms the theoretical basis for the empirical estimation of the R\&D cost elasticity in most previous studies in this area.

Now consider the case where the R\&D capital input into the firm's state $i$ production function actually consists of two R\&D inputs: internal (in-state) R\&D services $\left(R_{i t}^{i n t}\right)$ and external (out-of-state) R\&D services $\left(R_{i t}^{e x t}\right)$. Notice that the potential contribution of both an internal and external input is unique to $R \& D$ as a production factor since, unlike labor and physical capital, R\&D knowledge is not physically tied to a single location. This generalization of the previous case modifies the factor demand equation to:

$$
R_{i t}^{i n t}=\zeta Y_{i t}\left(\rho_{i t}^{i n t}\right)^{-\theta}\left(\rho_{i t}^{e x t}\right)^{\phi},
$$

where $\rho_{i t}^{\text {int }}$ is the internal (in-state) R\&D user cost (the user cost faced by the firm if it conducts $\mathrm{R} \& \mathrm{D}$ within state $i$ ) and $\rho_{i t}^{e x t}$ is the external (out-of-state) R\&D user cost (the user cost faced by the firm if it conducts R\&D outside of state $i$ ). $\quad-\theta$ is the elasticity of in-state $R \& D$ with respect to the internal $R \& D$ user cost, or simply the "internal-cost elasticity." $\phi$ is the elasticity of in-state R\&D with respect to the external R\&D user cost, or simply the "external-cost elasticity."

The external-cost elasticity reflects the degree of interstate mobility of R\&D activities. A finding of $\phi>0$ indicates that firms, or at least their R\&D funds, are able to relocate to some extent in response to changes in relative user costs. The sum of the external and internal R\&D elasticities, $\phi-\theta$, is the "aggregate" or "net" R\&D elasticity - the elasticity of $R \& D$ with respect to an equal-proportion change in all $R \& D$ 
user costs. I contend that it is this aggregate elasticity that most previous studies purport to estimate, though, as I argue below based on econometric considerations, it is more likely that these studies are identifying the internal-cost elasticity.

The factor demand equation (2) can be straightforwardly estimated in its loglinear form via least squares. However, there are several considerations one should take into account prior to doing so. First, there are likely to be unobserved state-specific factors that influence the R\&D spending in a state. For example, the level of human capital, the relative cost of labor, the quality of public infrastructure, environmental and labor regulations, natural amenities, and the cost of land are all factors that are fixed at the state level (at least over the sample period) and may influence where firms choose to locate their R\&D activities and the intensity with which they conduct R\&D in a given location. If these state-specific factors are correlated with the user cost of R\&D or any other independent variable in the regression, the estimator of the model's parameters will be inconsistent unless one controls for these fixed effects.

Similarly, state-level R\&D will be affected by aggregate, macroeconomic factors such as aggregate demand, technological opportunities, patent policy, and federal tax policy (though this factor also has state-specific effects for which I control ${ }^{26}$ ). Since state R\&D tax policy may be influenced on a year-to-year basis by these aggregate, year-specific factors, it is important to control for year effects in addition to the state effects.

Another possible confounding factor in determining state private $R \& D$ is the level of federal funding for industrial (company-performed) $R \& D$ in the state. If federally-funded industrial R\&D is complementary with company-funded industrial $\mathrm{R} \& \mathrm{D}$, then an increase in federal funding may induce more company funding. If, on the other hand, the two types of R\&D are substitutes, then increased federal funding may crowd-out private R\&D.

Incorporating the state fixed effects, the year effects, and federally-funded R\&D, and adding an i.i.d. error term, the log-linear R\&D factor demand equation becomes:

$$
\log \left(R_{i t}^{i n t}\right)=f_{i}+f_{t}-\theta \log \left(\rho_{i t}^{i n t}\right)+\phi \log \left(\rho_{i t}^{e x t}\right)+\alpha \log \left(Y_{i t}\right)+\beta \log \left(G_{i, t-1}\right)+\nu_{i t} .
$$

\footnotetext{
${ }^{26}$ Because of the deductibility of state taxes from federal taxable income, the effective federal corporate tax rate depends to some extent on the state corporate tax rate. Also, in some years, the R\&D credit taken by a firm is considered taxable. Thus, in these years the effective federal credit rate depends on the effective federal tax rate, which in turn depends on the state tax rate.
} 
where $Y_{i t}$ is state output and $G_{i, t-1}$ is federally-financed R\&D spending in the state. I use lagged $G$ in order to avoid any potential spurious contemporaneous correlation between company funds and federal funds.

In terms of introducing this equation to the data, obviously one of the most important considerations is how to measure $\rho_{i t}^{\text {ext }}$ empirically. I investigate a number of possible measures. My preferred measure is a weighted average of the R\&D user costs of states near state $i$, weighting by spatial proximity. Specifically, it is a weighted average of the user costs of the five closest states, where the weights are the inverse distances between population centroids. ${ }^{27}$ I construct similar, alternative measures using the ten closest states and all states. The first measure, using the five closest states, is preferred since of the three it provides the most cross-sectional variation. Retaining cross-sectional variation in the external cost measure is important as it allows one to identify the elasticity of $\mathrm{R} \& \mathrm{D}$ with respect to the external-cost while controlling for unobserved time-varying macroeconomic effects by including year dummies in the estimating equation. Nonetheless, as discussed in the following section, the results obtained in the regressions with year dummies hold up as well when the year dummies are replaced with time trends and time-varying macro variables. In fact, using this latter specification, I try three other potential measures of the external R\&D cost that are theoretically appealing but have little or no cross-sectional variation: minimum R\&D user cost among all other states (in year $t$ ), (2) proximity-weighted average of other states' costs based on proximity in technology space (measured by the inverse of the Euclidean distance between two states' composition of patents across technology classes), and (3) proximity-weighted average of other states' costs based on proximity in industry space (measured by inverse Euclidean distance between two states' composition of employment across industries).

Figure 3 provides a Moran scatterplot - i.e., a plot of the in-state R\&D user cost against the out-of-state R\&D user cost - for each of the three geographically weighted external cost measures in 2002. These scatterplots reveal three important patterns. First, they illustrate the extent to which the cross-state variation declines as one widens the number of neighboring states over which the out-of-state average cost is computed. Second, the 45 degree line in these plots indicates which states have an R\&D user cost above (northwest of the line) or below (southeast of the line)

\footnotetext{
${ }^{27}$ Distances are computed using the Great Circle formula using latitude and longitude data on state population centroids provided by the U.S. Census Bureau.
} 
the average cost of their neighbors. For example, states like Hawaii, Rhode Island, Georgia, New Jersey, and West Virginia have in-state R\&D costs that are considerably lower than the average cost of their neighboring states. The third and perhaps most interesting pattern revealed in Figure 3 is that there is a clear positive correlation between a state's own R\&D cost and the average cost of its near neighbors. This pattern is revealed most clearly in the top-left panel, where the out-of-state cost is the weighted average among the five closest states. Note, for instance, that all of the mid-Atlantic states - Virginia, Maryland, D.C., Delaware, and Pennsylvania - are found in the upper-right region of the plot, while Pacific West and New England states tend to be found in the lower-left region. The correlation coefficient is 0.23 (p-value $=0.10)$. Though further analysis, beyond the scope of this paper, would be required to fully assess this relationship, the strong positive correlation is at least suggestive of a strategic interaction between lawmakers in one state and lawmakers in nearby states when it comes to choosing $R \& D$ tax incentives. Such a positively-sloping reaction function is a necessary prerequisite for a so-called "race to the bottom" among states that many policymakers have argued has been happening in recent years with regard to $R \& D$ credits and other business tax incentives.

It should also be noted that, theoretically, the R\&D input(s) into the production function are R\&D capital services, which are unobserved. There are two possible ways to proxy for unobserved capital services. One can assume that the flow of R\&D capital services in a year is proportional to either $R \& D$ investment in that year or the $R \& D$ capital stock in that year. Given the inherent difficulty in measuring the depreciation rate of the R\&D stock and the fact that even-year data is missing prior to 1997, I opt to use R\&D investment instead, as is commonly done in the literature. As a robustness check, though, I also report results below based on an R\&D stock constructed using the perpetual inventory method assuming a $15 \%$ depreciation rate and filling in even-year investment data via interpolation between adjacent years.

\subsection{Dynamic Model}

The above factor demand model assumes that there are no adjustment costs/frictions associated with $\mathrm{R} \& \mathrm{D}$ capital. There is, however, ample evidence that firms face high adjustment costs relating to R\&D (Bernstein and Nadiri [1986]; Hall, Griliches, and Hausman [1986]; Hall and Hayashi [1988]; Himmelberg and Petersen [1990]; and Hall

$[1993 b])$. Not only may there be substantial costs involved with large year-to-year 
changes in $\mathrm{R} \& \mathrm{D}$ spending for a given $\mathrm{R} \& \mathrm{D}$ facility, but there also may be substantial costs associated with moving $R \& D$ activity from one state to another. Note that for a firm in one state to take advantage of another state's reduction in the R\&D user cost, the firm must not only conduct its R\&D in the latter state but must also generate income in that state, another potential cost of adjusting locations. All of these cost imply that in each period firms will only partially adjust R\&D to their desired levels.

To allow for partial adjustment of R\&D capital, I extend the above static model by including the lagged dependent variable:

$\log \left(R_{i t}^{i n t}\right)=\lambda \log \left(R_{i t-1}^{i n t}\right)+f_{i}+f_{t}-\theta \log \left(\rho_{i t}^{i n t}\right)+\phi \log \left(\rho_{i t}^{e x t}\right)+\alpha \log \left(Y_{i t}\right)+\beta \log \left(G_{i, t-1}\right)+\nu_{i t}$.

In this specification, $-\theta$ and $\phi$ identify the short-run R\&D elasticities with respect to the internal and external user costs, respectively. The long-run elasticities are given by $-\theta /(1-\lambda)$ and $\phi /(1-\lambda)$. Likewise, the long-run effects of output and federallyfunded industrial $R \& D$ can be obtained by dividing their coefficients by $(1-\lambda) .^{28}$

One must be careful, however, in using a dynamic model with the NSF state R\&D data. As mentioned above, the data is biannual up to 1997, at which point it becomes annual. Thus, $R_{i t-1}^{\text {int }}$ is missing for years 1981-1997. To see how this complicates the dynamic model, consider the standard partial-adjustment model:

$$
y_{i t}=\lambda y_{i t-1}+\boldsymbol{\beta} \mathbf{X}_{i t}+\varepsilon_{i t},
$$

where $y$ is the dependent variable and $\mathbf{X}$ is a vector of independent variables. In the biannual period (1981-1997), I don't observe the dependent variable lagged 1 year, but I do observe it lagged 2 years. Plugging the equation for $y_{i t-1}$ into the above equation yields a specification in terms of the 2-year lag of the dependent variable:

$$
\begin{aligned}
y_{i t} & =\lambda\left[\lambda y_{i t-2}+\boldsymbol{\beta} \mathbf{X}_{i t-1}+\varepsilon_{i t-1}\right]+\boldsymbol{\beta} \mathbf{X}_{i t}+\varepsilon_{i t} \\
& =\lambda^{2} y_{i t-2}+\boldsymbol{\beta}\left[\mathbf{X}_{i t}+\lambda \mathbf{X}_{i t-1}\right]+\left(\varepsilon_{i t}-\lambda \varepsilon_{i t-1}\right) \\
& =\lambda^{2} y_{i t-2}+\boldsymbol{\beta}\left[\mathbf{X}_{i t}+\lambda \mathbf{X}_{i t-1}\right]+v_{i t} .
\end{aligned}
$$

\footnotetext{
${ }^{28}$ The partial adjustment model should not be confused with ordinary serial correlation of the error term. Allowing serial correlation in the error term in equation (3) is not a substitute for including the lagged dependent variable in the equation if the true structural model is one of partial adjustment. (See Chamberlain (1984), Section 2.7, "Serial Correlation or partial adjustment?").
} 
In our context, this equation would express current R\&D as a function of R\&D lagged 2 years, and current and lagged values of the independent variables. Since all of the independent variables in $\mathbf{X}$ except $G$ (which, like $R$, is biannual until 1997) are observed annually, this equation can be estimated directly using a non-linear estimator. ${ }^{29}$ I perform such an estimation using non-linear least squares (NLLS) after imputing missing $G$ data based on adjacent years and obtain (and present below) results similar to the results from the linear estimation I describe next. The results presented in Section 4, however, will focus on the linear estimation as it does not rely on imputed data (for $G$ ).

If $\mathbf{X}_{i t-1}$ is uncorrelated with $\mathbf{X}_{i t}$, one can obtain consistent estimates of $\lambda$ and $\boldsymbol{\beta}$ using a linear estimator such as generalized least squares (GLS) and omitting the unobserved $\mathbf{X}_{i t-1}$ variables. In this case, the proper model is $y_{i t}=\lambda^{2} y_{i t-2}+\boldsymbol{\beta} \mathbf{X}_{i t}+v_{i t}$ for $t \leq 1997$ and $y_{i t}=\lambda y_{i t-1}+\boldsymbol{\beta} \mathbf{X}_{i t}+\varepsilon_{i t}$ for $t>1997$. These two equations can be estimated simultaneously by simply pooling the biannual and annual samples but allowing the coefficient on the lagged dependent variable, $\lambda$ or $\lambda^{2}$, to vary across the two periods (while constraining $\boldsymbol{\beta}$ to be equal over the entire sample). This is the main estimation strategy employed in this paper.

Of course, if the lagged values of the independent variables have an effect on current R\&D (independent of the effect from the current values of the independent variables), and the independent variables are autocorrelated, then the GLS within estimator will be biased away from zero. However, since the effects of lagged values is likely to be swamped by the effects of current values, this bias is likely to be small. As shown in Section 4, this conjecture is supported by the fact that the $\boldsymbol{\beta}$ estimates obtained via NLLS estimation of equation (6) match closely the GLS estimates of this linear specification.

\subsection{Estimation Strategy}

The identification of $\gamma$ can be obtained with the conventional difference-in-differences (DID) estimator. In the present panel data context with state fixed effects, the DID estimator is equivalent to the within-groups (or simply "within") estimator. Under the

\footnotetext{
${ }^{29}$ The error $v_{i t}$ will be $\mathrm{AR}(1)$ within state and may be heteroskedastic. I therefore estimate the above equation using a VC matrix that is heteroskedasticity-consistent (Hausman-White VC estimator) and allows for first-order autocorrelation of errors within-state. It is assumed that both $\mathbf{X}_{i t-1}$ and $\mathbf{X}_{i t}$ are orthogonal to $v_{i t}$.
} 
DID interpretation, the user cost of $R \& D$ can be thought of as the treatment variable and R\&D as the outcome variable. By controlling for the covariates $G$ and $Y$, we are allowing non-parallel outcomes between the treated and untreated groups (because the distribution of the covariates differs between the two groups). ${ }^{30}$

An identifying assumption in the conventional DID estimator is that treatment selection is random (uncorrelated with the error term). (In the context of the within least squares estimator, the analogous assumption is that the regressors are orthogonal to the error term of the equation). A well-known example of a violation of this assumption is the so-called "Ashenfelter's Dip" in which selection is dependent on past outcomes (Ashenfelter [1978]). In the current context, it could be that states with low levels of current $R \& D$ relative to their state average (which is captured in the fixed effect) may be compelled to enact or increase R\&D tax credits (decrease the R\&D user cost) in the following period. The inclusion of lagged R\&D in our preferred, dynamic specification above controls for such an effect, avoiding any such inconsistency in our estimator of the R\&D cost elasticity (unless the dependence derives from previous lags).

The DID/within estimation is implemented here via the standard approach of least squares estimation after the mean-difference transformation of the data. ${ }^{31}$ It should be noted that the within estimator is potentially biased in finite samples when the regressor set includes the lagged dependent variable (because $y_{i, t-1}$ is correlated with the error after mean-differencing, $\left.e_{i t}-\bar{e}_{i}\right)$. Fortunately, this correlation, and hence the bias, goes to zero as $T \rightarrow \infty$ (Nickell 1981). As a check on the unbiasedness of the estimates in this paper, I additionally estimate the model using the Bias-Corrected Least Squares Dummy Variable (LSDVC) estimator, which is based on adjusting the within estimates using an approximation of the bias term. ${ }^{32}$ The results confirm

\footnotetext{
${ }^{30}$ Meyer (1995) points out that in contexts in which the treatment effect (e.g., the R\&D cost elasticity) is not identical across individuals (states), the covariates should be interacted with the treatment variable. Abadie (2005) goes further, developing a semiparametric DID technique which allows treatment effects to be conditional on the observed covariates in a non-parametric fashion. In the present context, however, there is no compelling reason to think that the treatment effect, the R\&D cost elasticity, differs systematically across firms or states.

${ }^{31}$ It should be noted that some authors (e.g., Dagenais, Mohnen, and Therrien [1997]) opt for Tobit in estimating $R \& D$ or physical capital investment models because of the occurence of zero investment, especially at the firm level. In the current context, however, the Tobit estimator is unnecessary as there only is a single state-year observation (District of Columbia in 1983) with reported companyfunded R\&D equal to zero.

${ }^{32}$ Another approach to addressing the "Nickell" bias is the IV/GMM estimators of Anderson and
} 
that the original estimates are approximately unbiased (LSDVC results available upon request). ${ }^{33}$

Another econometric issue that must be addressed in this analysis is the potential autocorrelation of errors within states from using repeated cross-sections. This issue is easily handled by using the Feasible GLS estimator with a variance-covariance matrix in which errors are $\operatorname{AR}(1)$ within-state. I allow also for panel (state) heteroskedasticity.

\section{Results}

\subsection{Internal-Cost Elasticity Only}

The main results from estimating the log-linear model discussed above are shown in Table 2. Again, the estimator is the within-group/difference-in-difference estimator where state effects are removed by mean-differencing the data. All regressions include year dummies unless otherwise noted. The dependent variable in all regressions is the (mean-differenced) log of real company-funded industrial R\&D spending (deflated by the GDP deflator). ${ }^{34}$

To facilitate comparisons to previous studies of the R\&D cost elasticity, I first estimate an R\&D cost elasticity omitting the external R\&D user cost, $\rho_{i t}^{e x t}$. The results are shown in Columns (1) and (2) of Table 2. Column (1) shows the results of estimating the static regression model (equation (3)). The static model specification yields an elasticity of $\mathrm{R} \& \mathrm{D}$ with respect to internal, or in-state, $\operatorname{cost}(-\theta)$ of -1.81 with a robust standard error of 0.49 . Evaluated at the mean user cost for the sample, this elasticity implies that a one percentage point increase in a state's effective R\&D

Hsiao (1982), Arellano and Bond (1991), and Blundell and Bond (1998). The LSDVC estimator, however, has been shown to be more efficient (Judson and Owen 1999). See Bruno (2005) for a description of the LSDVC estimator and a routine for implementing it in Stata.

${ }^{33}$ The LSDVC estimates are not reported as the primary results because asymptotic standard errors cannot be computed for this estimator (rather standard errors must be bootstrapped) and standard methods of implementing LSDVC do not yet allow for specifying autoregressive correlation in the error structure.

${ }^{34}$ The deflation of R\&D has no effect in the regressions containing year effects (since these effects will pick up aggregate price movements), but it is necessary for the later regressions that omit year dummies. 
credit rate results in an increase in in-state $\mathrm{R} \& \mathrm{D}$ of around $2.5 \% .^{35}$ Gross State Product (GSP) is found to be positively and significantly associated with R\&D, with a coefficient of 1.25 (s.e. $=0.22) .{ }^{36}$ The estimated coefficient on federally-funded (industrial) $\mathrm{R} \& \mathrm{D}$ is $-0.08($ s.e. $=0.01)$. This estimate implies that a $10 \%$ increase in federal funding of industrial $\mathrm{R} \& \mathrm{D}$ in a given state would cause a $0.8 \%$ decline in private funding of industrial $R \& D$ in that state. This result of federal $R \& D$ funding crowding out private R\&D funding is consistent with the industry-level results reported by Mamuneas \& Nadiri (1996).

Column (2) shows the analogous results of estimating the dynamic, partialadjustment model (equation (4)). I find the short-run, or "impact," R\&D cost elasticity estimate is $-1.21($ s.e. $=0.44)$, which is statistically significant at below the $1 \%$ level. The estimated long-run elasticity, obtained as $-\hat{\gamma} /(1-\hat{\lambda})$, where $\hat{\lambda}$ is the estimated coefficient on the lagged dependent variable, is -2.18 (0.81) (standard error obtained via the Delta method). At the sample mean, this implies a one percentage point increase in the state effective credit rate results in an increase in in-state $R \& D$ of $1.7 \%$ in the short run and $3.0 \%$ in the long run. As in the static model, the effect of federally-funded R\&D is negative, with a short-run coefficient elasticity of -0.05 (0.01) and a long-run elasticity of -0.09 (0.02). The data clearly support the dynamic model over the static model, as evidenced by the statistically significant coefficients on the lagged dependent variable as well as the higher log-likelihood value for the dynamic model. Note that the coefficient on the lagged dependent variable is allowed to differ between the annual and biannual subperiods of the sample. The coefficient for the annual period is estimated to be 0.45 (s.e. $=0.05)$ while the coefficient estimate for the biannual period is 0.49 (s.e. $=0.04)$.

Our estimates of the long-run $\mathrm{R} \& \mathrm{D}$ cost elasticity here are similar, though somewhat larger, to those found in previous panel data studies that also allow for aggregate year effects and also omit an explicit external cost measure. In particular, Bloom, et al. (2002), using panel data from 1979-1997 on nine OECD countries, obtain a long-run $R \& D$ cost elasticity of -1.09 (in their preferred specification). Since the external R\&D user cost available to firms in one country may be highly correlated

\footnotetext{
${ }^{35}$ The marginal effect is calculated as $-\theta \frac{\partial \ln \rho}{\partial k_{i t}^{e}}=\frac{-\theta}{1-\left(k_{i t}^{e}+k_{f t}^{e}\right)-z\left(\tau_{i t}^{e}+\tau_{f t}^{e}\right)}$. The sample mean of this denominator is 0.73 .

${ }^{36}$ Data on nominal GSP going back to 1977 is available from the Bureau of Economic Analysis (BEA). I deflated nominal GSP using the aggregate GDP deflator in chained $2000 \$$ (the BEA only provides real GSP using state-specific deflators beginning with 1990).
} 
to that available to firms in other countries, the effect of the external R\&D user cost likely will be picked up to a large extent in their year effects. Thus, I would argue that the elasticity estimate from that study should be treated as an unbiased estimate of the internal (domestic) R\&D cost elasticity but may not necessarily be equal to the aggregate R\&D cost elasticity (though firms are likely far less mobile across countries than across states). As I show in the next subsection, explicitly accounting for external $\mathrm{R} \& \mathrm{D}$ costs results in an aggregate $\mathrm{R} \& \mathrm{D}$ cost elasticity that is far smaller than the internal R\&D cost elasticity, at least at the level of U.S. states.

\subsection{Internal- and External-Cost Elasticities}

Columns (3)-(5) of Table 2 show the results of explicitly adding the external (out-ofstate) R\&D user cost to the R\&D factor demand regression equation. As stated above, external costs were, to a large degree, implicitly taken account of in the regressions underlying Columns (1) and (2) by the year effects. The regressions underlying Columns (3)-(5) differ only in the measure of the out-of-state R\&D cost used in the regression. The first regression uses a weighted average of the R\&D user costs of the five states closest to state $i$. The weight between state $i$ and some nearby state $j$ is simply the inverse of the distance between their population centroids (as provided by the U.S. Census Bureau). The second regression uses a similarly constructed proximity-weighted average of the R\&D user costs of the 10 closest states; and the third regression uses a proximity-weighted average of all other states' R\&D user costs. As discussed above in relation to Figure 3, the first of the three measures is preferred since it contains the most cross-sectional variation, which is crucial for identification in these two-way fixed effects regressions since any aggregate, time-series variation in external costs is picked up by the year effects.

Adding the external cost is found to have only a small effect on the estimated internal-cost elasticity, which is consistent with the hypothesis that the year effects picked up much of the effect of external costs in previous regressions. Depending on which measure of out-of-state cost is used, the estimated in-state elasticity is between -1.26 and -1.43 in the short run, and between -2.29 and -2.58 in the long run (all significant below the $1 \%$ level). The out-of-state elasticity, on the other hand, is estimated to be positive and significant for each of the three measures of out-ofstate cost. Using the narrowest measure - a weighted-average of $R \& D$ costs in the five closest states, the short-run in-state elasticity is 2.06 , and statistically significant at the 
$5 \%$ level. The implied long-run in-state elasticity is 3.72. The implied aggregate-cost elasticity - the sum of the in-state and out-of-state elasticities - is relatively small and statistically insignificant.

As one broadens the measure of out-of-state cost by including more outside states in the weighted average, which reduces cross-sectional variation, the out-of-state elasticity estimate becomes increasingly imprecise. Nonetheless, even with the broader out-of-state cost measures used in the regressions underlying columns (3) and (4), the elasticity is found to be positive and significant at below the $5 \%$ level, and in no case is the aggregate-cost elasticity found to be significantly different from zero. ${ }^{37}$

Table 3 provides estimates based on analogous regressions to those underlying Columns (3)-(5) but replacing the year dummies with a year trend and GDP to capture aggregate macroeconomic shocks to R\&D spending. ${ }^{38}$ I also separately included $\log \left(r_{t}+\right.$ $\delta$ ) even though this term is already part of $\log \left(\rho_{i t}^{\text {in }}\right)$ and $\log \left(\rho_{i t}^{\text {out }}\right)$ to allow for possible endogeneity of the real interest rate. (Note $\log \left(r_{t}+\delta\right)$ is absorbed by the year effects in the previous regressions.) The estimated elasticities are qualitatively similar to those in Table 2, but are estimated here with much greater precision. Similar to the Table 2 results, the internal-cost elasticity is around -1.5 (in the short run) while the externalcost elasticity is around +1.6. The long-run internal and external elasticities are somewhat higher, at around -2.5 and +2.8 , respectively. Both in the short run and in the long run, the implied aggregate-cost elasticity is essentially zero (and precisely estimated). The results are quite consistent across the three measures of external cost.

The estimated coefficients on the other variables are virtually unchanged from the previous, two-way fixed-effects regressions. The elasticity of private R\&D with respect to federal $R \& D$ funding is precisely estimated at -0.06 . The coefficient on GSP is just slightly higher, at about 0.7 , than found in the previous regressions. Interestingly, I find that holding a state's own gross product constant, the gross product of the rest of the nation (i.e., GDP) has a negative and significant effect on state R\&D spending, with an elasticity around -0.9 . This suggests that as with costs, what matters for a state's R\&D demand is not the absolute size of its economy but rather its size

\footnotetext{
${ }^{37}$ This finding of a near-zero aggregate-cost elasticity is consistent with Bloom and Griffith (2001) who perform related regressions using cross-country panel data and also find an aggregate R\&D elasticity that is insignificantly different from zero (though the elasticities are estimated with far less precision than are those in this paper).

${ }^{38}$ Unreported regressions including either a quadratic time trend or presidential-term dummies yielded similar results.
} 
relative to the rest of the nation. That is, it appears that $\mathrm{R} \& \mathrm{D}$ activity may relocate out of state not just in response to favorable changes in out-of-state R\&D costs, but also in response to comparatively faster economic growth outside of the state.

\subsection{Robustness Checks}

In this subsection, I describe three checks on the robustness of the results described above. The first check involves using alternative measures, unrelated to geographic distance, of the out-of-state $R \& D$ user cost. The second check verifies that the estimates in Tables 2 and 3 are not biased due to the omission of even-year data between 19811997. I verify this by estimating the non-linear partial-adjustment model shown in equation (6) via non-linear least squares (NLLS). The third robustness check consists of replacing the flow (investment) of $R \& D$ as the dependent variable with an imputed measure of the stock of R\&D. A number of additional exercises, not shown here, also confirm the robustness of these regressions (results available upon request). These robustnesss checks include: including additional out-of-state factors (constructed as above) such as out-of-state GDP and population, allowing for potential R\&D datareporting/selection bias via a Heckman two-step estimator, and excluding Alaska and Hawaii from the sample.

Table 4 shows the results of using yet three other possible measures of the outof-state R\&D user cost in the one-way fixed effects specification. The first measure, used in the regression underlying Column (1), is the best, i.e., lowest, R\&D user cost available in a given year (among all states). If relocation costs are independent of distance (along geographical, technological, industrial, or any other dimension), then the minimum-cost state will be the relevant alternative location considered by firms in other states when deciding where and how much R\&D to conduct. Column (2) of Table 4 shows the results from measuring the out-of-state cost as a technology-based weighted average of other states' costs, where the weight between state $i$ and each other state is the inverse of the Euclidean distance between the two states' composition of patents across technology classes ${ }^{39}$. This measure is appropriate if firms focus disproportionately on states with other firms in similar technological fields when considering alternative R\&D locations. The third external-cost measure (Column (3)) is analogous but weights other states $\mathrm{R} \& \mathrm{D}$ costs according to the inverse Euclidean distance

\footnotetext{
${ }^{39}$ The annual number of patent grants in each state in each of 401 technology classes is provided by the U.S. Patent and Trademark Office.
} 
between state $i$ 's and each other state's composition of employment across industries. ${ }^{40}$

Though these alternative measures yield different estimates for the internalcost elasticity, compared with each other or with the elasticities from Table 3, they all yield an aggregate-cost elasticity that is, again, very close to zero (and statistically insignificant). The minimum-cost measure yields the lowest and least statistically significant estimates for the (short-run) internal- and external cost elasticities, at about -0.67 and 0.78 , respectively. The other technology and industry based measures yield estimates very similar to those using the distance-based measures of external costs. Using the technology-based measure results in short-run cost elasticities of -1.2 and 1.4, respectively, for the internal- and external-cost elasticities. Recall that the cost elasticities estimated using the distance-based measure (Table 3) were about -1.5 and 1.6, respectively. The industry-based measure yields similar, though slightly smaller, elasticities at about -1.1 and 1.3. As for the other explanatory variables, using these alternative external-cost measures has very little effect on their coefficient estimates.

As discussed in Section 3.2 above, because of the biannual nature of the R\&D data before 1997, the log-linear specification used thus far will provide consistent estimates only if the explanatory variables are independent of their (omitted) lagged values. Here I assess whether this identification assumption affects the estimates in any quantitatively important way by estimating the non-linear specification discussed earlier (equation (6)), which is robust to serial correlation in the explanatory variables. This specification allows one to use the even-year data available on the independent variables even though even-year data on the dependent variable, $R \& D$, is unobserved. ${ }^{41}$ Specifically, the estimating equation becomes:

$$
\begin{aligned}
\log \left(R_{i t}^{i n t}\right)= & \lambda^{2} \log \left(R_{i t-2}^{i n t}\right)+f_{i}+f_{t}-\theta \log \left(\rho_{i t}^{i n t}\right)-\theta \lambda \log \left(\rho_{i t-1}^{i n t}\right)+\phi \log \left(\rho_{i t}^{\text {ext }}\right)+\phi \lambda \log \left(\rho_{i t-1}^{\text {ext }}\right) \\
& +\alpha \log \left(Y_{i t}\right)+\alpha \lambda \log \left(Y_{i t-1}\right)+\beta \log \left(G_{i, t-1}\right)+\beta \lambda \log \left(G_{i, t-2}\right)+v_{i t},
\end{aligned}
$$

where $\{\gamma, \alpha, \beta\}$ are impact coefficients. The long-run effects are found by dividing the coefficients by $(1-\lambda)$.

\footnotetext{
${ }^{40}$ For each year, I compute employment shares for all states that have non-missing company $R \& D$ data using the lowest common level of industry aggregation possible for this set of states. Therefore, the level of aggregation is year-specific, but roughly-speaking, it matches the 3-digit SIC level. The data comes from the BLS ES-202 database.

${ }^{41}$ Even-year data is available for all explanatory variables except federally-funded R\&D spending. I impute even-year data for this variable by interpolating between adjacent years.
} 
I estimate this equation via non-linear least squares (NLLS). Table 5 reports the results from estimating the non-linear analogs to the three linear regressions of primary concern from above, namely the regressions underlying Columns (2) and (3) of Table 2 and Column 1 of Table 3. The first of these regressions includes federal R\&D, GSP, the internal R\&D user cost, and twice-lagged company R\&D. The second includes these variables plus the external user cost (measured using the proximityweighted average of the five closest states). The third replaces year effects with GDP and a year trend.

The estimated R\&D cost elasticities obtained from the non-linear model are similar to those obtained via the linear model, though the standard errors are higher. As with the linear model, the non-linear model yields an aggregate-cost elasticity that is considerably smaller than that estimated by previous studies and statistically insignificant from zero. Thus, the non-linear estimation confirms the linear model's results that (1) the internal cost elasticity is negative and above unity (in absolute value), (2) the external cost elasticity is positive and above unity, and (3) the aggregate-cost elasticity is small and not significantly different from zero. ${ }^{42}$

As a final robustness check, I experiment with using a measure of the R\&D stock rather than the R\&D investment flow for the dependent variable in the regressions. I construct a measure of the R\&D stock via a perpetual inventory of past investment assuming a depreciation rate of $15 \%$. I first fill in missing years of R\&D investment data via interpolation between adjacent years with non-missing data. If a state is missing more than 3 consecutive years of data, I drop these state-years from the sample beginning in the first year of missing data.

There are three main drawbacks to using the R\&D stock data instead of R\&D investment data (and hence why I use the investment data for the main results of the paper). First, there is substantial uncertainty regarding the true depreciation rate. Second, computing the stock entails using interpolated data. Third, the R\&D stock is very autocorrelated: In regressions based on the dynamic model using the stock, the coefficient on the (annual) lagged dependent variable generally is 0.75 or higher. This autocorrelation makes it difficult to accurately estimate the long-run effect of a given variable. With those caveats in mind, estimating the preferred specification

\footnotetext{
${ }^{42}$ One difference between the non-linear and linear results worth mentioning is that the coefficient on federally-funded R\&D is closer to zero and insignificant in the non-linear regressions. This is likely due to attenuation bias resulting from the imputation of even-year data for this variable.
} 
(that in Column 1 of Table 3) using the (mean-differenced log) R\&D stock measure as the dependent variable yields qualitatively similar results to those using R\&D flow. The estimated short-run internal-cost elasticity is $-0.24($ s.e. $=0.16)$ and the externalcost elasticity is $0.41(0.17){ }^{43}$ The implied long-run elasticities are, respectively, -0.99 (0.66) and 1.67 (0.71). The implied aggregate-cost elasticity is 0.17 (0.07) in the shortrun and 0.68 (0.31) in the long-run. In sum, using a measure of R\&D stock instead of the R\&D flow, the data still point toward a negative and significant internal-cost elasticity, a positive and significant external-cost elasticity, and a small and insignificant (though imprecisely estimated) aggregate-cost elasticity.

\subsection{Comparison to previous studies}

Table 6 summarizes the results of previous studies that estimate the R\&D cost elasticity. In the last row of the table, I include the estimated internal-cost elasticity from this paper based on the specifications that do not explicitly include the external user cost (though these specifications implicitly include the external user cost because they include year effects). Focusing on the more recent studies - in particular, those using post-1981 data (i.e., after the introduction of the U.S. federal R\&D tax credit) - one can see that the internal-cost estimates in this paper are at the upper end of the range of those found previously.

Hines (1993) performs a firm-level panel data estimation over the 1984-89 period, relying on the cross-firm variation in the tax treatment of $R \& D$ for certain U.S. multinational firms. He estimates a short-run R\&D cost elasticity of between -1.2 and -1.6 , and a long-run elasticity between -1.3 and -2.0 . Hall (1993a) obtains similar estimates: a short-run elasticity of -0.84 to -1.5 and a long-run elasticity of -2.0 to -2.7. Hall relies on cross-firm variation in tax positions for publicly-traded firms between 1981 and 1991. Bloom, et al. (2002), in their preferred dynamic specification, find a short-run elasticity of -0.14 and a long-run elasticity of -1.09 using a cross-country panel over the 1979-1997 period. None of these three studies control for the potential effect of federally-funded R\&D on private R\&D. Mamuneas and Nadiri (1996) estimate a cost function containing the after-tax price of company-funded R\&D, prices of other inputs, and the stock of federally-funded R\&D (both within-industry and external to industry). They use data from 1956-88 for 12 manufacturing industries.

\footnotetext{
${ }^{43}$ The full set of results from this regression are available from the author upon request.
} 
The variation in the R\&D price in their study comes from the fact that industries have different $R \& D$ input mixes and therefore different $R \& D$ economic depreciation rates. They obtain industry-specific estimates of the (short-run) R\&D price elasticity ranging from -0.94 to -1 . As in this paper, their estimates of cross-price elasticities suggest that company-funded and federally-funded R\&D are substitutes.

All of these previous studies ignore state-level R\&D tax credits in their calculations of the overall R\&D tax price, though this is less problematic for the studies using earlier sample periods since state R\&D tax credits became quantitatively more important over time. The resulting mismeasurement of the true extent of R\&D tax incentives could lead to overestimation of the $R \& D$ spending response to $R \& D$ tax credits.

It is illuminating also to compare the R\&D cost elasticity estimates to estimates in the literature of the user cost elasticity of physical capital. Interestingly, recent econometric studies of the (long-run) physical user cost elasticity have obtained estimates that are quite small, similar to the near-zero aggregate-cost elasticity estimates obtained in this paper. Chirinko, et al. (1999) find an elasticity of -0.25 . They also show that the elasticity implied by results from Cummins, Hassett, and Hubbard (1994) is -0.16 , and that implied by Cummins and Hassett (1992) is - 0.23 for equipment and -0.07 for structures. These results from the physical capital literature show that the finding in this paper of a small, near-zero aggregate $\mathrm{R} \& \mathrm{D}$ cost elasticity is not implausible; in fact it is quite consistent with the findings regarding physical capital's cost elasticity.

\section{Policy Implications and Conclusions}

This paper offers two important new findings to the literature. First, I find that the R\&D spending in a state is negatively impacted by R\&D tax incentives in other states, presumably as firms shift R\&D spending to the state or states with cheaper R\&D user costs. Second, the magnitude of this response (i.e., the elasticity) is nearly as large as the response to an increase in a state's own user cost. Each of these findings have very important policy implications.

The first finding indicates that a state's R\&D fiscal policies impose an externality on R\&D activity, and its associated benefits, in other states. Given recent U.S. federal court rulings, this finding raises interesting questions regarding the constitu- 
tionality of state R\&D tax credits (see Wilson [2005] for a discussion). Specifically, in the recent case Cuno v. DaimlerChrysler, et al. (2004), the Sixth Circuit Court of Appeals, citing a number of Supreme Court rulings, invalidated an Ohio investment tax credit on the grounds that it violated what is known as the "dormant Commerce Clause." This dormant clause of the U.S. Constitution holds that only Congress has the power to regulate interstate commerce and thus certain limits apply to a state's ability to adopt tax policies that affect commerce in other states. The Supreme Court has established that a tax violates this clause if it differentially, or "discriminatorily," "tax[es] the products manufactured or the business operations in any other State" (Boston Stock Exchange v. State Tax Commission [1977]). The Court has further stated that the fact that a tax statute discriminates against operations in other states via a tax credit instead of a tax is irrelevant (both legally and economically). In the Cuno decision, the Sixth Circuit Court of Appeals stated that the determination of whether a tax or credit is discriminatory should be decided "on the basis of 'a sensitive, case-by-case analysis of purposes and effects,'..." into whether "the provision 'will in its practical operation work discrimination against interstate commerce,..., by providing a direct commercial advantage to local business." (Cuno v. DaimlerChrysler, citing Supreme Court decisions West Lynn Creamery v. Healy [1994] and Bacchus Imports $v$. Dias [1984]). Similar cases currently are pending in a number of states. Thus, analyses into the effect of outside states' $R \& D$ tax credits into the $R \& D$ activity of a given state, such as the analysis done in this paper, are critical to the issue of whether state R\&D tax credits are constitutional. The findings of this paper suggest that state R\&D tax credits may in fact be discriminatory both in statute and in practice.

The second major finding of this paper - that the internal and external user cost elasticities are of opposite signs and roughly equal magnitudes - suggests nearly costless geographic mobility in R\&D activity. It also implies that the aggregate R\&D cost elasticity - the R\&D cost elasticity that is relevant for social welfare cost-benefit analyses of R\&D tax credits - is actually quite small, suggesting that the setting of R\&D tax credits by states (as opposed to only the federal government) is nearly a zero-sum game. For instance, if all states were to lower their R\&D user costs, e.g., by raising their tax credit rates, by the same percentage, aggregate private $R \& D$ in the nation would rise very little, if at all.

What these findings imply regarding the effectiveness of the U.S. federal R\&D tax credit depends on the degree of international mobility of R\&D. In the current 
era of globalization, it seems likely that large foreign and U.S. multinationals, which are responsible for the bulk of U.S. R\&D spending, may fairly easily reallocate R\&D activity to (from) the U.S. in response to favorable (unfavorable) changes in U.S. policy viz-a-viz foreign policy. Thus, the degree of international R\&D mobility remains an important topic for future research.

\section{References}

\section{References}

[1] Abadie, Alberto. "Semiparametric Difference-in-Differences Estimators." Review of Economic Studies 72, no. 1 (2005): 1-19.

[2] Anderson, T. W., and C. Hsiao. "Formulation and Estimation of Dynamic Models Using Panel Data." Journal of Econometrics, 1982.

[3] Arellano, Manuel, and Stephen R. Bond. "Some Tests of Specification for Panel Data: Monte Carlo Evidence and Application to Employment Equations." Review of Economic Studies, 1991.

[4] Ashenfelter, Orley. "Estimating the Effect of Training Programs on Earnings." Review of Economics and Statistics 60 (1978): 47-57.

[5] Baily, Martin, and Robert Z. Lawrence. "Tax Incentives for R\&D: What Do the Data Tell Us?" Study commissioned by the Council on Research and Technology, Washington, D.C.. September 1995.

[6] Beaulieu, Eugene, Kenneth J. McKenzie, and Jean-François Wen. "Do Taxes Matter for Firm Location? Evidence From Canadian Provinces." Mimeo, U. of Calgary, 2004.

[7] Berger, Philip G. "Explicit and Implicit Tax Effects of the R \& D Tax Credit." Journal of Accounting Research 31, no. 2 (1993).

[8] Bernstein, Jeffrey L., and M. Ishaq Nadiri. "Financing and Investment in Plant and Equipment and Research and Development"." Prices, Competition, and Equilibrium. Editors M. H. Pesaran and R. E. Quandt. Oxford: Philip Allan, 1986,233-48. 
[9] Bloom, Nick, and Rachel Griffith. "The Internationalisation of UK R\&D." Fiscal Studies 22, no. 3 (2001): 337-55.

[10] Bloom, Nick, Rachel Griffith, and John Van Reenen. "Do R\&D Tax Credits Work? Evidence From a Panel of Countries 1979-97 ." Journal of Public Economics 85, no. 1 (2002): 1-31.

[11] Blundell, Richard W., and Stephen R. Bond. "Initial Conditions and Moment Restrictions in Dynamic Panel Data Models." Journal of Econometrics, 1998.

[12] The Book of the States. The Council of State Governments (Lexington, KY) (Various Years).

[13] Bruno, Giovanni S. F. "Estimation and Inference in Dynamic Unbalanced PanelData Models With a Small Number of Individuals." Stata Journal, 2005.

[14] Buss, Terry F. "The Effect of State Tax Incentives on Economic Growth and Firm Location Decisions: An Overview of the Literature." Economic Development Quarterly, 2001.

[15] Cameron, Gavin. "On the Measurement of Real R\&D - Divisia Price Indices for UK Business Enterprise R\&D." Research Evaluation 6, no. 3 (1996): 215-19.

[16] Carlton, D. W. "Location and Employment Choices of New Firms: An Econometric Model With Discrete and Continuous Endogenous Variables." Review of Economics and Statistics, 1983.

[17] Chirinko, Robert S., Steven M. Fazzari, and Andrew P. Meyer. "How Responsive Is Business Capital Formation to Its User Cost? An Exploration With Micro Data." Journal of Public Economics 74 (1999): 53-80.

[18] Cummins, Jason G., and Kevin A. Hassett. "The Effects of Taxation on Investment: New Evidence From Firm Level Panel Data." National Tax Journal 45 (1992): 243-52.

[19] Cummins, Jason G., Kevin A. Hassett, and R. Glenn Hubbard. "A Reconsideration of Investment Behavior Using Tax Reforms As Natural Experiments." Brookings Papers on Economic Activity 2 (1994): 1-60. 
[20] Cuno, et al. v. DaimlerChrysler, et al. No. 01-3960, U.S. 6th Circuit Court of Appeals (2004).

[21] Dagenais, Marcel, Pierre Mohnen, and Pierre Therrien. "Do Canadian Firms Respond to Fiscal Incentives to Research and Development?" CIRANO Working Paper 97s-34 (1997).

[22] David, Paul A., Bronwyn H. Hall, and Andrew A. Toole. "Is public R\&D a complement or substitute for private R\&D? A Review of the Econometric Evidence." Research Policy 29 (2000): 497-529.

[23] Devereux, Michael P., and Rachel Griffith. "Taxes and the Location of Production: Evidence From a Panel of U.S. Multinationals." Journal of Public Economics, 1998.

[24] Grubert, Harry, and John Mutti. "Do Taxes Influence Where U.S. Corporations Invest? " National Tax Journal, 2000.

[25] Hall, Bronwyn. "R\&D Tax Policy During the 1980s: Success or Failure?" Tax Policy and the Economy.Vol. 7. Cambridge and London: MIT Press, 1993a,1-35.

[26] Hall, Bronwyn. "Industrial Research During the 1980s: Did the Rate of Return Fall?" Brookings Papers on Economic Activity, no. 2 (1993b): 289-343.

[27] Hall, Bronwyn, Zvi Griliches, and Jerry A. Hausman. "Patents and R and D: Is There a Lag?" International Economic Review 27, no. 2 (1986): 265-83.

[28] Hall, Bronwyn, and Fumio Hayashi. "Research and Development As an Investment." NBER Working Paper, no. 2973 (1989).

[29] Hall, Bronwyn, and Marta Wosinka. "Effectiveness of the California R\&D Tax Credit."1999a.

[30] Hall, Bronwyn, and Marta Wosinka. "The California R\&D Tax Credit: Description, History, and Economic Analysis."1999b.

[31] Hall, Robert E., and Dale W. Jorgenson. "Tax Policy and Investment Behavior." American Economic Review 57 (1967): 391-414. 
[32] Himmelberg, Charles P., and Bruce C. Peterson. "R\&D and Internal Finance: A Panel Study of Small Firms in High-Tech Industries." Review of Economics and Statistics 76, no. 1 (1994): 38-51.

[33] Hines, James R. Jr. "On the Sensitivity of R\&D to Delicate Tax Changes: The Behavior of U.S. Multinationals in the 1980s." Studies in International Taxation. Editors Alberto Giovanni, R. Glenn Hubbard, and Joel Slemrod. Chicago: University of Chicago Press, 1993,149-94.

[34] Jones, Charles I., and John C. Williams. "Too Much of a Good Thing? The Economics of Investment in R\&D." Journal of Economic Growth 5, no. 1 (2000): $65-85$.

[35] Judson, R. A., and A. L. Owen. "Estimating Dynamic Panel Data Models: A Guide for Macroeconomists." Economics Letters, 1999.

[36] Mamuneas, Theofanis P., and M. Ishaq Nadiri. "Public R\&D Policies and Cost Behavior of the US Manufacturing Industries." Journal of Public Economics 63, no. 1 (1996): 57-81.

[37] McCutchen, William M. Jr. "Estimating the Impact of the R\&D Tax Credit on Strategic Groups in the Pharmaceutical Industry." Research Policy 22, no. 4 (1993).

[38] Meyer, Bruce D. "Natural and Quasi-Experiments in Economics." Journal of Business and Economic Statistics 13, no. 2 (1995): 151-61.

[39] National Science Foundation, Division of Science Resources Statistics. "Research and Development in Industry: 2001," NSF 05-305, Project Officer, Raymond M. Wolfe (Arlington, VA 2005).

[40] Newman, Robert J., and Dennis H. Sullivan. "Econometric Analysis of Business Tax Impacts on Industrial Location: What Do We Know, and How Do We Know It?" Journal of Urban Economics 23 (1988): 215-34.

[41] Oates, Wallace A. Fiscal Federalism. New York, NY: Harcourt Brace. 1972.

[42] ÓhUallacháin, Brendán, and Mark A. Satterthwaite. "Sectoral Growth Patterns at the Metropolitan Level: An Evaluation of Economic Development Incentives." Journal of Urban Economics 31 (1992): 25-58. 
[43] Paff, Lolita A. "State-Level R\&D Tax Credits: A Firm-Level Analysis." Topics in Economic Analysis \& Policy (forthcoming).

[44] Papke, Leslie E. "Subnational Taxation and Capital Mobility: Estimates of TaxPrice Elasticities." National Tax Journal, 1987.

[45] Papke, Leslie E. "Interstate Business Tax Differentials and New Firm Location: Evidence From Panel Data." Journal of Public Economics, 1991.

[46] Plesko, George A., and Robert Tannenwald. "Measuring the Incentive Effects of State Tax Policies Toward Capital Investment." FRB Boston Working Paper 01-4, 2001.

[47] Sigalla, Fiona, and Alan D. Viard. "Would a Research Tax Credit Be a Good Investment for Texas?" Southwest Economy, Federal Reserve Bank of Dallas, no. 2 (1999): 1-7.

[48] Significant Features of Fiscal Federalism, American Council on Intergovernmental Affairs (Orange Grove, NJ) (Various Years).

[49] State Science and Technology Institute (SSTI). "State Research and Development Tax Incentives."1997.

[50] Stark, Kirk and Daniel J. Wilson "What Do We Know about the Interstate Economic Effects of State Tax Incentives?," Georgetown Journal of Law and Public Policy IV (1), 2006.

[51] State Tax Handbook, Commerce Clearing House, Inc. (Chicago, IL) (Various Years).

[52] Swenson, C. W. "Some Tests of the Incentive Effects of the Research and Experimentation Tax Credit." Journal of Public Economics 49, no. 2 (1992): 203-18.

[53] Tiebout, Charles M. "A Pure Theory of Local Expenditures." Journal of Political Economy, 1956.

[54] Wheeler, David, and Ashoka Mody. "International Investment Location Decisions: The Case of U.S. Firms." Journal of International Economics, 1992. 
[55] Wilson, John D. "A Theory of Interregional Tax Competition." Journal of Urban Economics, 1986.

[56] Wilson, John D. "Theories of Tax Competition." National Tax Journal, 1999.

[57] Wilson, Daniel J. "Are State R\&D Tax Credits Constitutional? An Economic Perspective." Federal Reserve Bank of San Francisco Economic Letter, 2005-11, June 3, 2005.

[58] Wu, Yonghong. "The Effect of State R\&D Tax Credits in Stimulating Private R\&D Expenditure: A Cross-State Empirical Analysis." Mimeo (2003). 
[59] Zodrow, George R., and Peter Mieszkowski. "Pigou, Tiebout, Property Taxation, and the Underprovision of Local Public Goods." Journal of Urban Economics, 1986.

\section{Appendix A}

\subsection{R\&D User Cost Measurement}

In this appendix, I discuss the formulas, assumptions, and source data used in constructing the R\&D user cost for a representative firm in each of the 50 states and the District of Columbia. As discussed in Section 2, the general formula for the (after-tax) user cost of R\&D capital (per dollar of investment) is:

$$
\rho_{i t}=\frac{1-s\left(k_{i t}^{e}+k_{f t}^{e}\right)-z_{t}\left(\tau_{i t}^{e}+\tau_{f t}^{e}\right)}{1-\left(\tau_{i t}^{e}+\tau_{f t}^{e}\right)}\left[r_{t}+\delta\right],
$$

where $t$ indexes time. The subscript $i$ indicates a state-level variable while the subscript $f$ is used for federal level variables. $r_{t}$ is the real interest rate and $\delta$ is the economic depreciation rate of the $\mathrm{R} \& \mathrm{D}$ stock. $\tau_{i t}^{e}$ and $\tau_{f t}^{e}$ denote the effective corporate income tax rates; $z_{t}$ denotes the PDV of tax depreciation allowances; $k_{i t}^{e}$ and $k_{f t}^{e}$ denote the effective rate of the $R \& D$ tax credit (at the state and federal levels, respectively); and $s$ is the share of R\&D that qualifies for preferential tax treatment. Data from IRS Statistics on Income indicate that roughly $s=0.5$.

\subsubsection{Effective Corporate Tax Rates}

$\tau_{f t}^{e}$ is the effective federal corporate tax rate. In the United States, the effective federal corporate tax rate is lower than the actual statutory rate $\left(\tau_{f t}\right)$ because the taxes a firm pays to its state(s) are deductible from its federal tax liability. Thus, $\tau_{f t}^{e}=\tau_{f t}\left(1-\tau_{i t}^{e}\right)$.

$\tau_{i t}^{e}$ is the effective corporate tax rate in state $i$. Some states allow full deductibility of federal income taxes from state taxable income, some allow only partial deductibility, and some allow no deductibility at all. Thus, $\tau_{i t}^{e}=\tau_{i t}\left(1-\lambda \tau_{f t}^{e}\right)$, where $\tau_{i t}$ is the state's statutory tax rate and $\lambda$ is the fraction of federal taxes that are deductible from state taxable income. $\lambda$ is either $0\left(\tau_{i t}^{e}=\tau_{i t}\right)$ or 1 , except in Iowa and Missouri where $\lambda=0.5$. Many states have multiple statutory tax rates which increase 
stepwise with income; in the calculation of user costs, I use the states top marginal tax rate.

Notice, however, that $\tau_{i t}^{e}$ is a function of $\tau_{f t}^{e}$ and vice versa. This yields two equations in two unknowns and thus it is straightforward to solve for each. The solutions are:

$$
\begin{aligned}
\tau_{f t}^{e} & =\frac{\tau_{f t}\left(1-\tau_{i t}\right)}{1-\lambda \tau_{f t} \tau_{i t}}, \text { and } \\
\tau_{i t}^{e} & =\tau_{i t}\left[\frac{1-\lambda \tau_{f t}}{1-\lambda \tau_{f t} \tau_{i t}}\right] .
\end{aligned}
$$

\subsubsection{Value of Depreciation Allowances}

Regarding depreciation allowances for $\mathrm{R} \& \mathrm{D}$ expenditures, all states have chosen to follow the federal tax code, thus there is not a separate $z$ for the state and federal levels. As laid out in Hall and Jorgenson (1967), the PDV of tax depreciation allowances for an asset assuming straight-line depreciation is $1 / T$, where $T$ is the tax life of the asset. Expenditures on "qualified" R\&D may be immediately expensed (i.e., $T=1$ ), while non-qualified R\&D is subject to the same tax depreciation rules as non-R\&D capital. I assume a tax life of $T \approx 20$ for non-qualified $R \& D$ assets. The present value of depreciation allowances for all R\&D then becomes $z_{t}=s(1)+(1-s)(1 / 20)=0.525$ (assuming $s=0.5)$.

\subsubsection{Effective Credit Rates}

$k_{i t}^{e}$ and $k_{f t}^{e}$ are the effective rates of $\mathrm{R} \& \mathrm{D}$ tax credits at the state and federal levels, respectively. The effective credit rate depends on whether the credit applies to all R\&D expenditures or only R\&D expenditures above a designated base level, and, if the latter, how the base is defined. If the R\&D tax credit applies to all R\&D expenditures (i.e., a non-incremental credit), then the value of the credit is simply the credit rate: $k_{i t}^{e}=k_{i t}$, where $k_{i t}$ is the statutory credit rate in state $i$. Connecticut, New York, and West Virginia currently have such a credit.

All other states with R\&D tax credits, the credit applies to incremental R\&D above a base level. In some states, the base is defined as current sales times a $n$-period moving average of the $\mathrm{R} \& \mathrm{D}$-to-sales ratio. In these cases, $k_{i t}^{e}=k_{i t}\left(B_{i t}-\frac{1}{n} \sum_{s=1}^{n}\left(1+r_{t-s}\right)^{-s} B_{i, t+s}\right)$, where $B$ is an indicator which takes the value 1 if $R \& D$ expenditures is above its incremental R\&D base that period and zero otherwise. For example, in 2004, $n$ is 2 for Kansas; 3 for Illinois, Maine, and Missouri; and 4 for Pennsylvania. Most states, 
however, currently mirror the federal definition of the base, which is defined as sales (averaged over the previous 4 years) times the average $\mathrm{R} \& \mathrm{D}$-to-sales ratio during some fixed-period (typically 1984-1988). In these cases, $k_{i t}^{e}=k_{i t} B_{i t}$.

Another important consideration is that in some states (e.g., California), the credit is "recaptured," i.e., the part or all of the credit itself is considered taxable. This reduces the value of the credit by the amount of the credit (as defined by one of the 3 equations above) times the tax rate: $k_{i t, \text { new }}^{e}=k_{i t}^{e}\left(1-\omega \tau_{i t}^{e}\right)$, where $\omega$ is the share of the credit subject to recapture.

For the purposes of this paper, I assume $B_{i t}=1$ for all states and in all years. This assumption can be justified by the fact that in the Compustat manufacturing sample analyzed in Hall (1993a), the percentage of firms with current R\&D above their base $\left(B_{i t}=1\right)$ was $60-80 \%$ depending on year (between 1981-1991). The formulas above for $k_{i t}^{e}$ and $k_{f t}^{e}$ also assume that the representative firm underlying the calculations has taxable income against which to apply the credit (or, alternatively, that the credit is refundable). In reality, firms are allowed to carry back the federal credit up to three years and carry forward up to fifteen years. Most states with R\&D tax credits replicate the federal carry-back and carry-forward rules. As with the $B_{i t}=1$ assumption, the assumption that firms have taxable income and therefore will use their credits in the current year is supported by the firm-level statistics reported in Hall (1993a). She finds that during the 1981-91 period, over $80 \%$ of firms had taxable income in any given year. Note, additionally, that neither of these assumptions should have any effect on the empirical results in this paper as long as the likelihood of a firm having taxable income or R\&D above base does not covary systematically with $R \& D$ spending across states.

A number of states have a multi-tiered schedule of $R \& D$ tax credit rates, with rates typically declining with the level of qualified R\&D. ${ }^{44}$ When calculating the value of $R \& D$ tax credits, the default credit rate I use in the calculation is the rate for the highest tier. This choice is appropriate since the distribution of U.S. industrial R\&D over project sizes is extremely left-skewed. Specifically, according to the NSF, $65 \%$ of U.S. industrial R\&D in 2000 was accounted for by companies with $R \& D$ programs above $\$ 100$ million; such companies represent less than $1 \%$ of all R\&D-performing companies in the U.S.. ${ }^{45}$ The results discussed below are based on a user cost computed using the

\footnotetext{
${ }^{44}$ The only state where the marginal credit rate increases with level of R\&D expenditures is Connecticut (after 1993).

${ }^{45}$ Earlier data from the IRS also supports the contention that firms that claim R\&D tax credits
} 
top-tier (minimum) credit rate for each state. However, results were also obtained based on two alternative user costs, one using median credit rates and one using maximum credit rates. The results were insensitive to which of the three user costs were used.

As for the federal R\&D tax credit, it has been incremental since it was introduced in 1981. The definition of the base level and the extent to which the credit is recaptured, has varied over time. The base level for determining qualified R\&D was a 3-year moving average from 1981 to 1990. Starting in 1991, it became a fixed period (1984-88) average (except in the case of start-up firms). ${ }^{46}$ The federal R\&D tax credit was not recaptured (taxable) from 1981 to 1988 ; in 1989, 50\% of the credit was recaptured; since 1989, 100\% of the credit has been recaptured. ${ }^{47}$

\subsection{Source Data for User Cost Ingredients}

Compiling information for the 50 states plus the District of Columbia over 1981-2004 on the specifics of R\&D tax credits (credit rates, base definitions, and recapture provisions) was a challenging task. SSTI (1997) and Sigalla and Viard (1999) provided a starting point. The SSTI study provides a state-by-state description of R\&D tax incentives in place in 1996. Sigalla and Viard (see their Table 1) provide the credit rates, base period, and year of introduction for the state R\&D tax credits available in 1998. From the Sigalla and Viard table, we were able to back-fill the R\&D tax credit information for all states that had them, back to their year of introduction. For these states, we checked with state tax agencies for whether these states changed their tax credit details between the introduction and 2004. ${ }^{48}$ For all other states, we checked online corporate income tax forms for recent years to see if they had enacted R\&D tax credits since 1998 (many had). The tax forms provide all necessary ingredients for the R\&D user

are generally quite large. Of the total amount of $\mathrm{R} \& \mathrm{D}$ tax credits claimed in 1992, 70\% came from corporations with $\$ 250$ million or more in assets. Only $9 \%$ came from corporations of $\$ 10$ million or less. See OTA (1995).

${ }^{46}$ For firms started up after 1984, the base starts at $3 \%$ of sales but is then adjusted thereafter based on lagged R\&D.

${ }^{47}$ The "recapturing" of the federal R\&D tax credit is not specified in the section of the Internal Revenue Code (IRC) detailing the credit (Section 41). Rather, recapturing is accomplished in the IRC (Section $280 C(c)(1)$ ) by requiring firms to subtract the credit amount from the deduction of R\&D expenditures (which would otherwise be permitted under Sections 162 and 174).

${ }^{48}$ Interestingly, only one state has ever repealed a previously-introduced R\&D tax credit. New Hampshire introduced a credit in 1993 and then repealed it after just two years. 
cost formula (1) above.

Historical state corporate tax rates (and the extent to which federal taxes are deductible) were compiled from a number of sources. For recent years, data came primarily from various editions of the State Tax Handbook (various years) and The Book of the States (various years), as well as actual state tax forms. Data for earlier years came from various editions of Significant Features of Fiscal Federalism (various years) and The Book of the States (various years). Additional information was provided by the Tax Foundation.

Following Chirinko, Fazzari, and Meyer (1999), I measure $r$ using the S\&P 500 dividend-price ratio plus its long-run average growth rate of $2.4 \%$. The (non-timevarying) depreciation rate $(\delta)$ of $\mathrm{R} \& \mathrm{D}$ capital is assumed to equal $15 \%$. Note the $\left(r_{t}+\delta\right)$ term in equation (1) does not vary by state. Thus, since we use the log of $\rho_{t}$ in our regressions, the effect of $\left(r_{t}+\delta\right)$ will be picked up in the year effects whenever year effects are present. 
Figure 1. Number and Average Value of State R\&D Tax Credits in the U.S., 1981-2006

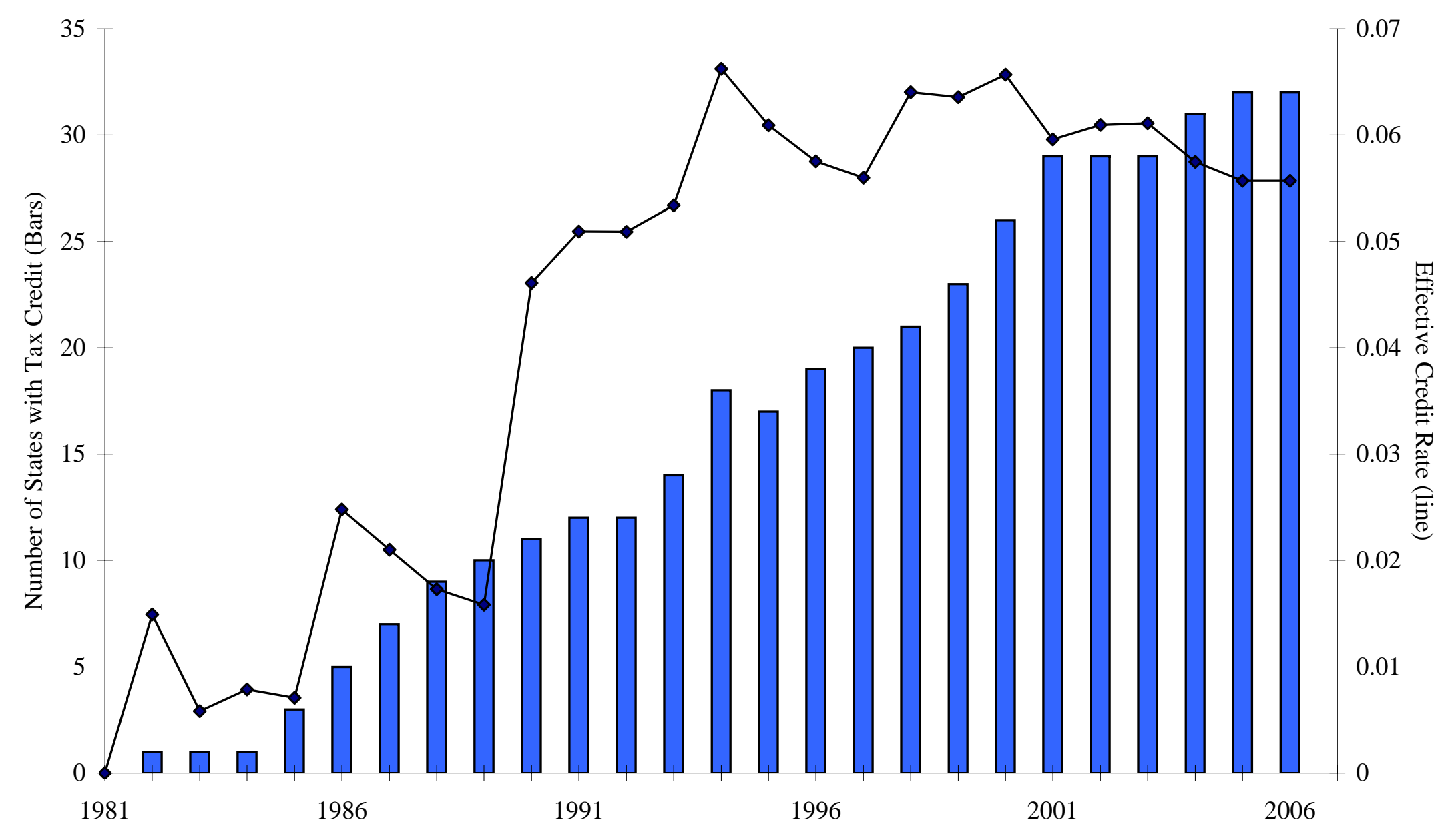

Source: Author's Calculations 
Figure 2. Coefficient of Variation across States in the R\&D User Cost, 1981-2004

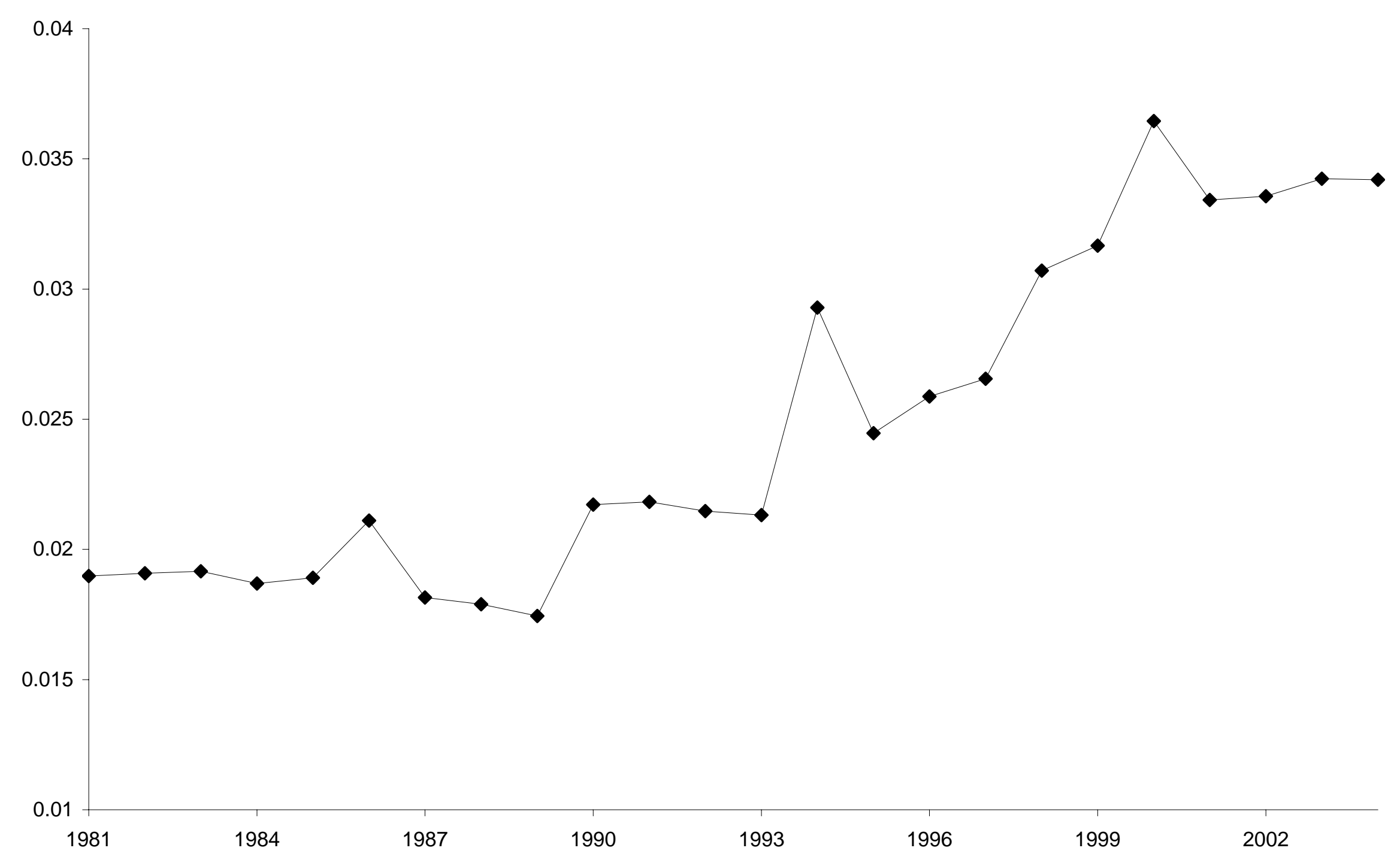




\section{Figure 3}

\section{In-State vs. Out-of-state R\&D User Costs, 2002}
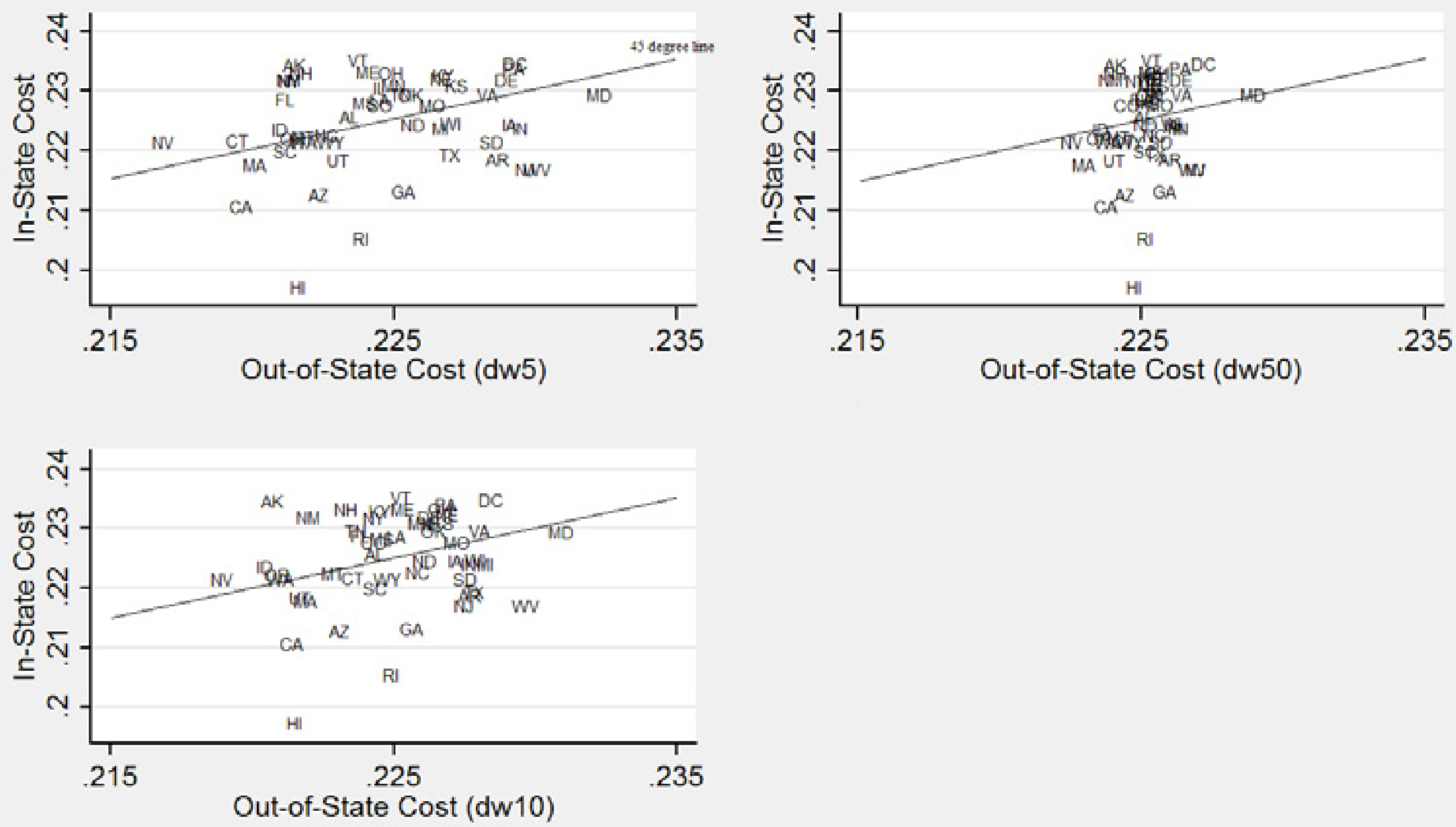

dw5 $=$ (geographic) proximity-weighted average of costs in closest 5 states dw10 $=$ (geographic) proximity-weighted average of costs in closest 10 states dw50 $=$ (geographic) proximity-weighted average of costs in all other states 
Table 1.

Summary of State-Level R\&D Tax Credits as of 2006

\begin{tabular}{|c|c|c|c|c|}
\hline State & $\begin{array}{c}\text { Year } \\
\text { Enacted }\end{array}$ & $\begin{array}{c}\text { Statutory Credit } \\
\text { Rate }^{1}\end{array}$ & Base Definition & $\begin{array}{c}\text { Effective } \\
\text { Credit Rate }^{2}\end{array}$ \\
\hline Arizona & 1994 & $11.0 \%$ & Federal (Fixed-period)) & $11.0 \%$ \\
\hline California & 1987 & $15.0 \%$ & Federal (Fixed-period)) & $13.7 \%$ \\
\hline Connecticut & 1993 & $6.0 \%$ & NonIncremental & $6.0 \%$ \\
\hline Delaware & 2000 & $10.0 \%$ & Average of Previous 4 Years & $0.9 \%$ \\
\hline Georgia & 1998 & $10.0 \%$ & Federal (Fixed-period)) & $10.0 \%$ \\
\hline Hawaii & 2000 & $20.0 \%$ & Nonincremental & $20.0 \%$ \\
\hline Idaho & 2001 & $5.0 \%$ & Federal (Fixed-period)) & $5.0 \%$ \\
\hline Illinois & 1990 & $6.5 \%$ & Average of Previous 3 Years & $0.5 \%$ \\
\hline Indiana & 1985 & $5.0 \%$ & Federal (Fixed-period)) & $5.0 \%$ \\
\hline Iowa & 1985 & $6.5 \%$ & Federal (Fixed-period)) & $6.5 \%$ \\
\hline Kansas & 1988 & $6.5 \%$ & Average of Previous 2 Years & $0.4 \%$ \\
\hline Louisiana & 2003 & $8.0 \%$ & Federal (Fixed-period)) & $8.0 \%$ \\
\hline Maine & 1996 & $5.0 \%$ & Average of Previous 3 Years & $0.4 \%$ \\
\hline Maryland & 2000 & $10.0 \%$ & Average of Previous 4 Years & $0.9 \%$ \\
\hline Massachussetts & 1991 & $10.0 \%$ & Federal (Fixed-period)) & $10.0 \%$ \\
\hline Minnesota & 1982 & $2.5 \%$ & Federal (Fixed-period)) & $2.5 \%$ \\
\hline Missouri & 1994 & $6.5 \%$ & Average of Previous 3 Years & $0.5 \%$ \\
\hline Montana & 1999 & $5.0 \%$ & Federal (Fixed-period)) & $5.0 \%$ \\
\hline Nebraska & 2006 & $3.0 \%$ & Average of Previous 2 Years & $0.2 \%$ \\
\hline New Jersey & 1994 & $10.0 \%$ & Federal (Fixed-period)) & $10.0 \%$ \\
\hline North Carolina & 1996 & $5.0 \%$ & Federal (Fixed-period)) & $5.0 \%$ \\
\hline North Dakota & 1988 & $4.0 \%$ & Federal (Fixed-period)) & $4.0 \%$ \\
\hline Ohio & 2004 & $7.0 \%$ & Average of Previous 3 Years & $0.5 \%$ \\
\hline Oregon & 1989 & $5.0 \%$ & Federal (Fixed-period)) & $5.0 \%$ \\
\hline Pennsylvania & 1997 & $10.0 \%$ & Average of Previous 4 Years & $0.9 \%$ \\
\hline Rhode Island & 1994 & $16.9 \%$ & Federal (Fixed-period)) & $16.9 \%$ \\
\hline South Carolina & 2001 & $5.0 \%$ & Federal (Fixed-period)) & $5.0 \%$ \\
\hline Texas & 2001 & $5.0 \%$ & Federal (Fixed-period)) & $5.0 \%$ \\
\hline Utah & 1999 & $6.0 \%$ & Federal (Fixed-period)) & $6.0 \%$ \\
\hline Vermont & 2003 & $10.0 \%$ & Average of Previous 4 Years & $0.9 \%$ \\
\hline West Virginia & 1986 & $10.0 \%$ & Non-Incremental & $10.0 \%$ \\
\hline Wisconsin & 1986 & $5.0 \%$ & Federal (Fixed-period)) & $4.6 \%$ \\
\hline Median & NA & $6.5 \%$ & NA & $5.0 \%$ \\
\hline Other states & N/A & N/A & N/A & N/A \\
\hline
\end{tabular}

${ }^{1}$ Highest-tier credit rate for states with different credit rates for different levels of investment.

${ }^{2} \mathrm{~A}_{\mathrm{it}}{ }^{\mathrm{c}}$ from equation (1) in the text.

${ }^{3}$ Tax Wedge is percentage difference between after-tax user cost of R\&D and pre-tax user cost $(r+\delta)$. 
TABLE 2.

DID/Within Estimates of R\&D Cost Elasticities (With Year Effects)

Dependent Variable: Company R\&D

\begin{tabular}{|c|c|c|c|c|c|}
\hline Explanatory Variable & $(1)$ & $(2)$ & $\begin{array}{c}5 \text { Closest } \\
(3) \\
\end{array}$ & $\begin{array}{c}10 \text { Closest } \\
\text { (4) }\end{array}$ & $\begin{array}{l}\text { All } \\
\text { (5) } \\
\end{array}$ \\
\hline Internal (In-state) R\&D cost & $\begin{array}{l}-1.81 * * * \\
(0.49)\end{array}$ & $\begin{array}{l}-1.21 * * * \\
(0.44)\end{array}$ & $\begin{array}{l}-1.43^{* * *} \\
(0.45)\end{array}$ & $\begin{array}{l}-1.37 * * * \\
(0.45)\end{array}$ & $\begin{array}{l}-1.26 \text { *** } \\
(0.44)\end{array}$ \\
\hline External (Out-of-State) R\&D cost & & & $\begin{array}{l}2.06 \text { ** } \\
(0.94)\end{array}$ & $\begin{array}{l}2.44 * * \\
(1.18)\end{array}$ & $\begin{array}{l}4.71 * * \\
(2.13)\end{array}$ \\
\hline Federal R\&D (-1) & $\begin{array}{l}-0.08 * * * \\
(0.01)\end{array}$ & $\begin{array}{l}-0.05 * * * \\
(0.01)\end{array}$ & $\begin{array}{l}-0.05 * * * \\
(0.01)\end{array}$ & $\begin{array}{l}-0.05 * * * \\
(0.01)\end{array}$ & $\begin{array}{l}-0.05^{* * *} \\
(0.01)\end{array}$ \\
\hline Company R\&D (-1) [biannual periods] & & $\begin{array}{l}0.49 \text { *** } \\
(0.04)\end{array}$ & $\begin{array}{l}0.47^{* * *} \\
(0.04)\end{array}$ & $\begin{array}{l}0.47 \text { *** } \\
(0.04)\end{array}$ & $\begin{array}{l}0.47 \text { *** } \\
(0.04)\end{array}$ \\
\hline Company R\&D (-1) [annual periods] & & $\begin{array}{l}0.45 \text { *** } \\
(0.05)\end{array}$ & $\begin{array}{l}0.45^{* * *} \\
(0.05)\end{array}$ & $\begin{array}{l}0.45 \text { *** } \\
(0.05)\end{array}$ & $\begin{array}{l}0.45^{* * *} \\
(0.05)\end{array}$ \\
\hline State GDP & $\begin{array}{l}1.25 \text { *** } \\
(0.22)\end{array}$ & $\begin{array}{l}0.73^{* * * *} \\
(0.18)\end{array}$ & $\begin{array}{l}0.63 \text { *** } \\
(0.19)\end{array}$ & $\begin{array}{l}0.64 \text { *** } \\
(0.19)\end{array}$ & $\begin{array}{l}0.64 \text { *** } \\
(0.19)\end{array}$ \\
\hline \multicolumn{6}{|c|}{ Implied Estimates (based on coefficients above): } \\
\hline Short Run Aggregate-Cost Elasticity & & & $\begin{array}{r}0.63 \\
(0.93)\end{array}$ & $\begin{array}{r}1.07 \\
(1.17)\end{array}$ & $\begin{array}{r}3.44 \\
(2.13)\end{array}$ \\
\hline Long-Run Internal-Cost Elasticity & & $\begin{array}{l}-2.18 * * * \\
(0.81)\end{array}$ & $\begin{array}{l}-2.58 * * * \\
(0.83)\end{array}$ & $\begin{array}{l}-2.48 * * * \\
(0.82)\end{array}$ & $\begin{array}{l}-2.29 * * * \\
(0.80)\end{array}$ \\
\hline Long-Run External-Cost Elasticity & & & $\begin{array}{l}3.72 * * \\
(1.72)\end{array}$ & $\begin{array}{l}4.41 \text { ** } \\
(2.18)\end{array}$ & $\begin{array}{l}8.54 \text { ** } \\
(3.94)\end{array}$ \\
\hline Long Run Aggregate-Cost Elasticity & & & $\begin{array}{r}1.14 \\
(1.69)\end{array}$ & $\begin{array}{r}1.93 \\
(2.13)\end{array}$ & $\begin{array}{r}6.24 \\
(3.92)\end{array}$ \\
\hline Year Dummies? & Yes & Yes & Yes & Yes & Yes \\
\hline Year Coverage & 1981-2004 & $1981-2004$ & 1981-2004 & $1981-2004$ & 1981-2004 \\
\hline Number of state-year obs. & 365 & 365 & 365 & 365 & 365 \\
\hline Log Likelihood & 111.489 & 135.076 & 138.219 & 137.978 & 138.321 \\
\hline
\end{tabular}

Notes: All variables are measured in natural logs. Standard errors are shown in parentheses. Standard errors are robust to panel (state) heteroskedasticity and AR(1) within-state autocorrelation. The out-of-state R\&D costs are geographicalproximity-weighted averages of R\&D user costs in the five closest states (Column (3)), ten closest states (Column (4)), and all other states (Column (5)).

$* * *$ denotes significance at the $99 \%$ level

** denotes significance at the $95 \%$ level

* denotes significance at the $90 \%$ level 
TABLE 3.

DID/Within Estimates of R\&D Cost Elasticities (Without Year Effects)

Dependent Variable: Company R\&D

\begin{tabular}{|c|c|c|c|}
\hline Explanatory Variable & $\begin{array}{c}5 \text { closest } \\
\text { (1) }\end{array}$ & $\begin{array}{c}10 \text { closest } \\
(2)\end{array}$ & $\begin{array}{l}\text { All } \\
(3)\end{array}$ \\
\hline Internal (In-State) R\&D cost & $\begin{array}{l}-1.50 \text { *** } \\
(0.44)\end{array}$ & $\begin{array}{l}-1.48^{* * *} \\
(0.43)\end{array}$ & $\begin{array}{l}-1.41^{* * *} \\
(0.43)\end{array}$ \\
\hline External (Out-of-State) R\&D cost & $\begin{array}{l}1.64 \text { *** } \\
(0.50)\end{array}$ & $\begin{array}{l}1.64 \text { *** } \\
(0.50)\end{array}$ & $\begin{array}{l}1.62 \text { *** } \\
(0.51)\end{array}$ \\
\hline Fed R\&D (-1) & $\begin{array}{l}-0.06 \text { *** } \\
(0.01)\end{array}$ & $\begin{array}{l}-0.06^{* * *} \\
(0.01)\end{array}$ & $\begin{array}{l}-0.06 \text { *** } \\
(0.01)\end{array}$ \\
\hline Year & $\begin{array}{l}0.03 \text { *** } \\
(0.01)\end{array}$ & $\begin{array}{l}0.03 \text { ** } \\
(0.01)\end{array}$ & $\begin{array}{l}0.03 \text { ** } \\
(0.01)\end{array}$ \\
\hline State GDP & $\begin{array}{l}0.70 \text { *** } \\
(0.16)\end{array}$ & $\begin{array}{l}0.72 \text { *** } \\
(0.15)\end{array}$ & $\begin{array}{l}0.77^{* * *} \\
(0.16)\end{array}$ \\
\hline National GDP & $\begin{array}{l}-0.92 \text { ** } \\
(0.46)\end{array}$ & $\begin{array}{l}-0.92 \text { ** } \\
(0.46)\end{array}$ & $\begin{array}{l}-0.88 * \\
(0.49)\end{array}$ \\
\hline Company R\&D (-1) [biannual periods] & $\begin{array}{l}0.43 \text { *** } \\
(0.03)\end{array}$ & $\begin{array}{l}0.44^{* * *} \\
(0.03)\end{array}$ & $\begin{array}{l}0.45^{* * *} \\
(0.03)\end{array}$ \\
\hline Company R\&D (-1) [annual periods] & $\begin{array}{l}0.40 \text { *** } \\
(0.03)\end{array}$ & $\begin{array}{l}0.40 \text { *** } \\
(0.03)\end{array}$ & $\begin{array}{l}0.40 \text { *** } \\
(0.04)\end{array}$ \\
\hline Real Interest Rate plus Depreciation Rate & $\begin{array}{l}0.31 \text { ** } \\
(0.13)\end{array}$ & $\begin{array}{l}0.28 * * \\
(0.13)\end{array}$ & $\begin{array}{c}0.26 * \\
(0.15)\end{array}$ \\
\hline \multicolumn{4}{|c|}{ Implied Estimates (based on coefficients above): } \\
\hline Short Run Aggregate-Cost Elasticity & $\begin{array}{r}0.14 \\
(0.20)\end{array}$ & $\begin{array}{r}0.16 \\
(0.20)\end{array}$ & $\begin{array}{r}0.20 \\
(0.22)\end{array}$ \\
\hline Long-Run Internal-Cost Elasticity & $\begin{array}{l}-2.51 \text { *** } \\
(0.74)\end{array}$ & $\begin{array}{l}-2.47^{* * *} \\
(0.74)\end{array}$ & $\begin{array}{l}-2.34 \text { *** } \\
(0.72)\end{array}$ \\
\hline Long-Run External-Cost Elasticity & $\begin{array}{l}2.75^{* * *} \\
(0.82)\end{array}$ & $\begin{array}{l}2.74^{* * *} \\
(0.83)\end{array}$ & $\begin{array}{l}2.68 \text { *** } \\
(0.85)\end{array}$ \\
\hline Long Run Aggregate-Cost Elasticity & $\begin{array}{r}0.24 \\
(0.32)\end{array}$ & $\begin{array}{r}0.27 \\
(0.33)\end{array}$ & $\begin{array}{r}0.34 \\
(0.36)\end{array}$ \\
\hline Year Dummies? & No & No & No \\
\hline Year Coverage & $1981-2004$ & $1981-2004$ & $1981-2004$ \\
\hline Number of state-year obs. & 365 & 365 & 365 \\
\hline Log Likelihood & 134.417 & 134.497 & 133.662 \\
\hline
\end{tabular}

Notes: All variables are measured in natural logs. Standard errors are shown in parentheses. Standard errors are robust to panel (state) heteroskedasticity and AR(1) within-state autocorrelation. The out-of-state $R \& D$ costs are geographical-proximity-weighted averages of R\&D user costs in the five closest states (Column (1)), ten closest states (Column (2)), and all other states (Column (3)).

*** denotes significance at the $99 \%$ level

** denotes significance at the $95 \%$ level

* denotes significance at the $90 \%$ level 
TABLE 4.

Estimated Elasticities Using Alternative External-Cost Measures

Dependent Variable: Company R\&D

\begin{tabular}{|c|c|c|c|}
\hline Explanatory Variable & $\begin{array}{l}\text { Min } \\
(1)\end{array}$ & $\begin{array}{l}\text { Patent } \\
(2)\end{array}$ & $\begin{array}{c}\text { Employment } \\
\text { (3) }\end{array}$ \\
\hline Internal (In-State) R\&D cost & $\begin{array}{l}-0.67 * \\
(0.35)\end{array}$ & $\begin{array}{l}-1.23 * * * \\
(0.39)\end{array}$ & $\begin{array}{l}-1.13 * * * \\
(0.40)\end{array}$ \\
\hline External (Out-of-State) R\&D cost & $\begin{array}{r}0.78 \\
(0.49)\end{array}$ & $\begin{array}{l}1.42 \text { *** } \\
(0.48)\end{array}$ & $\begin{array}{l}1.27 \text { *** } \\
(0.48)\end{array}$ \\
\hline Fed R\&D (-1) & $\begin{array}{l}-0.06 * * * \\
(0.01)\end{array}$ & $\begin{array}{l}-0.06 * * * \\
(0.01)\end{array}$ & $\begin{array}{l}-0.06 \text { *** } \\
(0.01)\end{array}$ \\
\hline Year & $\begin{array}{l}0.03 * * \\
(0.01)\end{array}$ & $\begin{array}{l}0.03 \text { ** } \\
(0.01)\end{array}$ & $\begin{array}{l}0.03 * * \\
(0.01)\end{array}$ \\
\hline State GDP & $\begin{array}{l}0.85 \text { *** } \\
(0.16)\end{array}$ & $\begin{array}{l}0.82 \text { *** } \\
(0.16)\end{array}$ & $\begin{array}{l}0.83 \text { *** } \\
(0.16)\end{array}$ \\
\hline National GDP & $\begin{array}{l}-1.02 \\
(0.50)\end{array}$ & $\begin{array}{l}-1.011^{* *} \\
(0.49)\end{array}$ & $\begin{array}{l}-1.03 \text { ** } \\
(0.48)\end{array}$ \\
\hline Company R\&D (-1) [biannual periods] & $\begin{array}{l}0.46 \text { *** } \\
(0.03)\end{array}$ & $\begin{array}{l}0.45 * * * \\
(0.03)\end{array}$ & $\begin{array}{l}0.45 * * * \\
(0.03)\end{array}$ \\
\hline Company R\&D (-1) [annual periods] & $\begin{array}{l}0.39 * * * \\
(0.04)\end{array}$ & $\begin{array}{l}0.40^{* * *} \\
(0.04)\end{array}$ & $\begin{array}{l}0.39 \text { *** } \\
(0.04)\end{array}$ \\
\hline Real Interest Rate plus Depreciation Rate & $\begin{array}{l}0.44^{* *} \\
(0.17)\end{array}$ & $\begin{array}{l}0.27 * \\
(0.15)\end{array}$ & $\begin{array}{c}0.25 * \\
(0.15)\end{array}$ \\
\hline \multicolumn{4}{|c|}{ Implied Estimates (based on coefficients above): } \\
\hline Short Run Aggregate-Cost Elasticity & $\begin{array}{r}0.11 \\
(0.27)\end{array}$ & $\begin{array}{r}0.18 \\
(0.22)\end{array}$ & $\begin{array}{r}0.14 \\
(0.22)\end{array}$ \\
\hline Long-Run Internal-Cost Elasticity & $\begin{array}{l}-1.10 \text { * } \\
(0.57)\end{array}$ & $\begin{array}{l}-2.05 \text { *** } \\
(0.67)\end{array}$ & $\begin{array}{l}-1.86 \text { *** } \\
(0.68)\end{array}$ \\
\hline Long-Run External-Cost Elasticity & $\begin{array}{r}1.29 \\
(0.79)\end{array}$ & $\begin{array}{l}2.36 \text { *** } \\
(0.80)\end{array}$ & $\begin{array}{l}2.10 * * * \\
(0.79)\end{array}$ \\
\hline Long Run Aggregate-Cost Elasticity & $\begin{array}{r}0.18 \\
(0.44)\end{array}$ & $\begin{array}{r}0.30 \\
(0.37)\end{array}$ & $\begin{array}{r}0.24 \\
(0.35)\end{array}$ \\
\hline Year Dummies? & No & No & No \\
\hline Year Coverage & 1981-2004 & 1981-2004 & 1981-2004 \\
\hline Number of state-year obs. & 365 & 365 & 365 \\
\hline Log Likelihood & 131.570 & 133.259 & 132.749 \\
\hline
\end{tabular}

Notes: All variables are measured in natural logs. Standard errors are shown in parentheses. Standard errors are robust to panel (state) heteroskedasticity and AR(1) within-state autocorrelation. The out-of-state R\&D costs are as follows: Column (1) -- minimum R\&D user cost among all states (by year); Column (2) -- weighted average of R\&D user costs in all other states, weighting by similarity between own state's and other state's patent composition across technology classes; Column (3) -- weighted average of R\&D user costs in all other states, weighting by similarity between own state's and other state's employment composition across 3-digit industries.

*** denotes significance at the $99 \%$ level

** denotes significance at the $95 \%$ level

* denotes significance at the $90 \%$ level 
TABLE 5.

NLLS Estimated Elasticities from Nonlinear Specification Dependent Variable: Company R\&D

\begin{tabular}{|c|c|c|c|}
\hline Explanatory Variable & (1) & $\begin{array}{l}5 \text { Closest } \\
\text { (2) }\end{array}$ & $\begin{array}{l}5 \text { Closest } \\
\text { (3) }\end{array}$ \\
\hline Internal (In-State) R\&D cost & $\begin{array}{l}-1.12 \text { *** } \\
(0.40)\end{array}$ & $\begin{array}{l}-1.82 * * * \\
(0.50)\end{array}$ & $\begin{array}{l}-1.86 \text { *** } \\
(0.51)\end{array}$ \\
\hline External (Out-of-State) R\&D cost & & $\begin{array}{l}1.49 * * \\
(0.60)\end{array}$ & $\begin{array}{l}2.10^{* * *} \\
(0.59)\end{array}$ \\
\hline Fed R\&D (-1) & $\begin{array}{r}-0.01 \\
(0.02)\end{array}$ & $\begin{array}{r}-0.01 \\
(0.02)\end{array}$ & $\begin{array}{r}-0.04 \\
(0.02)\end{array}$ \\
\hline Year & & & $\begin{array}{r}0.00 \\
(0.00)\end{array}$ \\
\hline State GDP & $\begin{array}{c}0.23 * \\
(0.12)\end{array}$ & $\begin{array}{l}0.344^{* * *} \\
(0.13)\end{array}$ & $\begin{array}{l}0.35 \text { ** } \\
(0.15)\end{array}$ \\
\hline National GDP & & & $\begin{array}{r}0.31 \\
(0.21)\end{array}$ \\
\hline Company R\&D (-2) & $\begin{array}{l}0.62 \text { *** } \\
(0.04)\end{array}$ & $\begin{array}{l}0.62 \text { *** } \\
(0.04)\end{array}$ & $\begin{array}{l}0.59 \text { *** } \\
(0.04)\end{array}$ \\
\hline Real Interest Rate plus Depreciation Rate & & & $\begin{array}{c}0.43 * \\
(0.24)\end{array}$ \\
\hline \multicolumn{4}{|c|}{ Implied Estimates (based on coefficients above): } \\
\hline Short Run Aggregate-Cost Elasticity & & $\begin{array}{r}-0.33 \\
(0.43)\end{array}$ & $\begin{array}{r}0.24 \\
(0.33)\end{array}$ \\
\hline Long-Run Internal-Cost Elasticity & $\begin{array}{l}-2.95 * * * \\
(1.07)\end{array}$ & $\begin{array}{l}-4.84 * * * \\
(1.38)\end{array}$ & $\begin{array}{l}-4.54 \text { *** } \\
(1.29)\end{array}$ \\
\hline Long-Run External-Cost Elasticity & & $\begin{array}{l}3.97 \text { ** } \\
(1.67)\end{array}$ & $\begin{array}{l}5.13 \text { *** } \\
(1.45)\end{array}$ \\
\hline Long Run Aggregate-Cost Elasticity & & $\begin{array}{r}-0.87 \\
(1.13)\end{array}$ & $\begin{array}{r}0.59 \\
(0.79)\end{array}$ \\
\hline Year Dummies? & Yes & Yes & No \\
\hline Year Coverage & $1981-2004$ & $1981-2004$ & 1981-2004 \\
\hline Number of state-year obs. & 343 & 343 & 343 \\
\hline Adj R-Squared & 0.577 & 0.585 & 0.567 \\
\hline
\end{tabular}

Notes: All variables are measured in natural logs. Standard errors are shown in parentheses. Standard errors are robust to panel (state) heteroskedasticity and AR(1) within-state autocorrelation. The out-of-state R\&D cost used in Columns (2) and (3) is a geographicalproximity-weighted average of R\&D user costs in the five closest states.

*** denotes significance at the $99 \%$ level

$* *$ denotes significance at the $95 \%$ level

* denotes significance at the $90 \%$ level 
Table 6.

Estimated R\&D Cost Elasticities Found in Previous Studies (for, or including, the U.S.)

\begin{tabular}{|c|c|c|c|c|c|}
\hline Authors & $\begin{array}{l}\text { Short-Run } \\
\text { Elasticity }\end{array}$ & $\begin{array}{l}\text { Long-Run } \\
\text { Elasticity }\end{array}$ & Data Type & Data Source & Sample Period \\
\hline $\begin{array}{l}\text { Eisner, Albert, and Sullivan (1983) } \\
\text { (19) }\end{array}$ & insig from 0 & NA & $\sim 600$ firms & McGraw-Hill surveys & $1980-82$ \\
\hline Mansfield (1986) & $\sim-.35$ & -0.30 to -0.60 & 110 firms & Survey & 1981-83 \\
\hline Baily and Lawrence (1995) & -0.75 & -1.30 & 12 2-digit industries & NSF R\&D by industry & 1960-89 \\
\hline Berger (1993) & -1.0 to -1.5 & -1.74 & 263 firms (balanced) & Compustat & 1975-88 \\
\hline Hall (1993) & -1.0 to -1.5 & -2.0 & 800 firms (unbalanced) & Compustat & 1980-91 \\
\hline McCutchen (1993) & -0.28 & -0.29 to -0.35 & $\begin{array}{l}20 \text { large pharmaceutical } \\
\text { firms }\end{array}$ & IMS data and $10-\mathrm{K}$ 's & $1975-85$ \\
\hline Hines (1993) & -1.2 to -1.6 & -1.3 to -2.0 & 116 multinationals & Compustat & 1984-89 \\
\hline Mamuneas and Nadiri (1996) & -0.94 to -1 & NA & $\begin{array}{l}12 \text { 2-dig. manufacturing } \\
\text { industries }\end{array}$ & NSF R\&D by industry & $1956-88$ \\
\hline Bloom, Griffith, and Van Reenen (2002) & -0.14 & -1.09 & 9 OECD countries & OECD BERD database & 1979-97 \\
\hline $\begin{array}{l}\text { Present Study -- Internal-Cost Elasticity (omitting } \\
\text { explicit measure of external cost) }\end{array}$ & -1.2 & -2.2 & U.S. States (unbalanced) & $\begin{array}{l}\text { NSF R\&D by state, state tax } \\
\text { codes }\end{array}$ & 1981-2004 \\
\hline
\end{tabular}

Source: Updated by Author from Table 3 of OTA

(1995). 